\title{
The Elemental, Mineralogical, IR, DTA and XRD Analyses Characterized Clays and Clay Minerals of Central and Eastern Uganda
}

\author{
I. Z. Mukasa-Tebandeke ${ }^{1}$, P. J. M. Ssebuwufu ${ }^{1}$, S. A. Nyanzi ${ }^{1}$, A. Schumann ${ }^{2}$, \\ G. W. A. Nyakairu' ${ }^{1}$, M. Ntale ${ }^{1}$, F. Lugolobi ${ }^{3}$ \\ ${ }^{1}$ Department of Chemistry, Makerere University, Kampala, Uganda \\ ${ }^{2}$ Department of Geology, Makerere University, Kampala, Uganda \\ ${ }^{3}$ Department of Earth Sciences, Wesleyan University, Middletown, CT, USA \\ Email: ${ }^{\text {ishamukasa@cns.mak.ac.ug }}$
}

Received 10 January 2015; accepted 12 February 2015; published 17 February 2015

Copyright (C) 2015 by authors and Scientific Research Publishing Inc.

This work is licensed under the Creative Commons Attribution International License (CC BY). http://creativecommons.org/licenses/by/4.0/

CC) (i) Open Access

\section{Abstract}

The results on the elemental and mineralogical compositions of clays from Central Uganda differed from those from the volcanic sediments of the Mt. Elgon in Eastern Uganda. Utilisation of the two types of clays should be strict after understanding their structural differences. Whereas elemental, mineralogical, DTA, IR, XRD and pH data on selected clays from Kumi, Nakawa, Seeta, Kajansi, Kawuku, Lwanda, Chodah and Umatengah indicated that they were kaolinites. Similar data on clays from Mutufu, Budadiri, Chelel and Siron indicated that they were largely smectites. The IR data accumulated on Kawuku, Kajansi, Lwada, Seeta, Chodah, Umatengah, Kumi and Nakawa clays revealed they were largely kaolinites yet that on Mutufu, Chelel, Budadiri and Siron clays indicated they were smectite-rich.

\section{Keywords}

Mineralogy, Structures, Differential Thermal Analysis, Chemical Composition, X-Ray Diffraction, Kaolinite, Diagenesis, Smectite

\section{Introduction}

Clays are collectively called alumino-silicates, they contain aluminium oxide and silicon dioxide as universal minerals; and clays were classified into phyllosilicates and layers silicates [1]. Clays are known to be natural,

"Corresponding author.

How to cite this paper: Mukasa-Tebandeke, I.Z., Ssebuwufu, P.J.M., Nyanzi, S.A., Schumann, A., Nyakairu, G.W.A., Ntale, M. and Lugolobi, F. (2015) The Elemental, Mineralogical, IR, DTA and XRD Analyses Characterized Clays and Clay Minerals of Central and Eastern Uganda. Advances in Materials Physics and Chemistry, 5, 67-86.

http://dx.doi.org/10.4236/ampc.2015.52010 
earthy, fine-grained materials, which develop plasticity when mixed with a limited quantity of water [2]. They are composed principally of silica, alumina and water often with iron, alkali or alkaline earth metals [3].

Clays consist of small particles of dimension $3 \mu \mathrm{m}$ diameter and are adsorbents used to filter or remove solids and color in oils [4]. Clays have differing but inter-related structures. Whereas bentonites or montmorillonites are closely related to layer silicates, kaolinites are strangely different and show resemblance to clays related to them by diagenesis [1] [5]. The differences in clay structures arise from the way the silica tetrahedra and alumina octahedra align in the structure as well as the differences in the number of the polyhedra and other ions present in the entire structure.

The kaolinite has a single tetrahedral silica sheet and single octahedral alumina sheet, a combination which repeats itself indefinitely. The crystal structure consists of unit layers, which are stack on one another and held together finally by hydrogen bonding among the hydroxide ions of the octahedral sheet of one layer and the oxygen of the tetrahedral sheet of the adjacent layer. Kaolinite is a clay mineral with the chemical composition $\mathrm{Al}_{2} \mathrm{Si}_{2} \mathrm{O}_{5}(\mathrm{OH})_{4}$ or $\mathrm{Al}_{2} \mathrm{O}_{3} \cdot 2 \mathrm{SiO}_{2} \cdot 2 \mathrm{H}_{2} \mathrm{O}[6]$.

Halloysites exist in two states of hydration: hydrated and metahalloysite, and are typically formed by hydrothermal alteration of alumino-silicate minerals [6].

The illite is a group of micas of the igneous and metamorphic rocks that has a unit layer composed of octahedral sheets sandwiched among tetrahedral sheets. Presence of potassium ions among these sheets results in increased thickness of the layer. The chemical formula is given as $\left(\mathrm{K}, \mathrm{H}_{3} \mathrm{O}\right)(\mathrm{Al}, \mathrm{Mg}, \mathrm{Fe})_{2}(\mathrm{Si}, \mathrm{Al})_{4} \mathrm{O}_{10}\left[(\mathrm{OH})_{2},\left(\mathrm{H}_{2} \mathrm{O}\right)\right]$ but there is considerable ion substitution [8]. It occurs as aggregates of small monoclinic grey to white crystals [9].

The montmorillonites are made of an alumina octahedral sheet between two silica tetrahedral sheets. Nontronite is the iron (III) rich member of the smectite group of clay minerals. Nontronites typically have a chemical composition consisting of more than $\sim 30 \% \mathrm{Fe}_{2} \mathrm{O}_{3}$ and less than $\sim 12 \% \mathrm{Al}_{2} \mathrm{O}_{3}$ ignited basis. A typical structural formula for nontronite is $\mathrm{Ca}_{5}\left(\mathrm{Si}_{7} \mathrm{Al}_{8} \mathrm{Fe}_{2}\right)\left(\mathrm{Fe}_{3.5} \mathrm{Al}_{4} \mathrm{Mg}_{.1}\right) \mathrm{O}_{20}(\mathrm{OH})_{4}$. The dioctahedral sheet of nontronite is composed mainly of trivalent iron $\left(\mathrm{Fe}^{3+}\right)$ cations, although some substitution by trivalent aluminium $\left(\mathrm{Al}^{3+}\right)$ and divalent magnesium $\left(\mathrm{Mg}^{2+}\right)$ does occur. The tetrahedral sheet is composed mainly of silicon $\left(\mathrm{Si}^{4+}\right)$. On the basis of relative percentages of aluminium, silicon and alkali metals or alkaline earth metals, the clays studied can be asserted to satisfy the formulae and structures [9] [10].

Clay are phyllosilicate minerals that impart plasticity to clay and which harden upon firing or drying [11]. Clays are broadly categorised as kaolinites and smectites. The kaolinites include kaolinite, halloysite, and dickite [12] and the smectites include montmorillonite, nontronite, saponite and hectorite [1]. Whereas the kaolinite minerals consist of a single tetrahedral silica sheet and a single octahedral alumina sheet forming repetitive sheets in infinite dimensions, smectites may consist of a single silica tetrahedral among two or more alumina octahedral [5] and the structures illustrating these two types of clays are shown in Figure 1 (kaolinite) and Figure 2 (montmorillonite). Halloysite and metahalloysite belong to kaolinite group and differ from each other by way of degree of hydration [5].

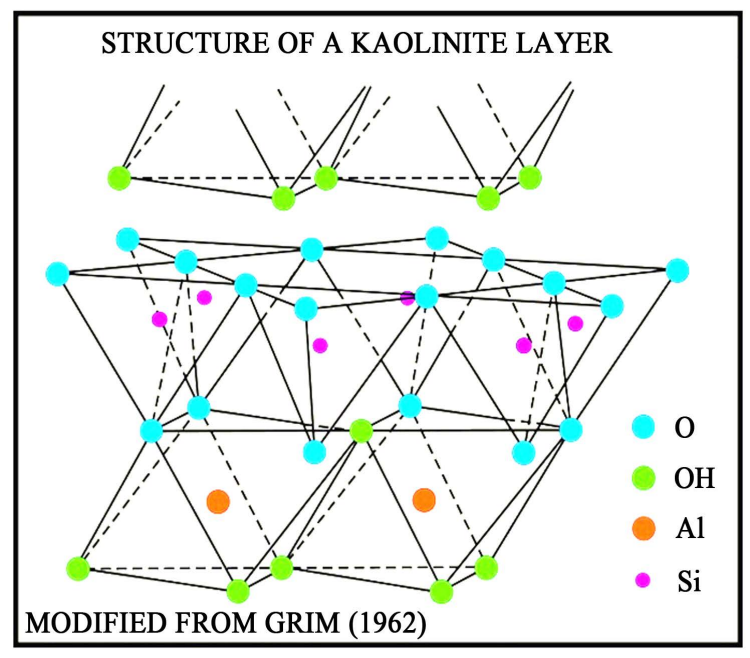

Figure 1. Representation of kaolinite clay [7]. 


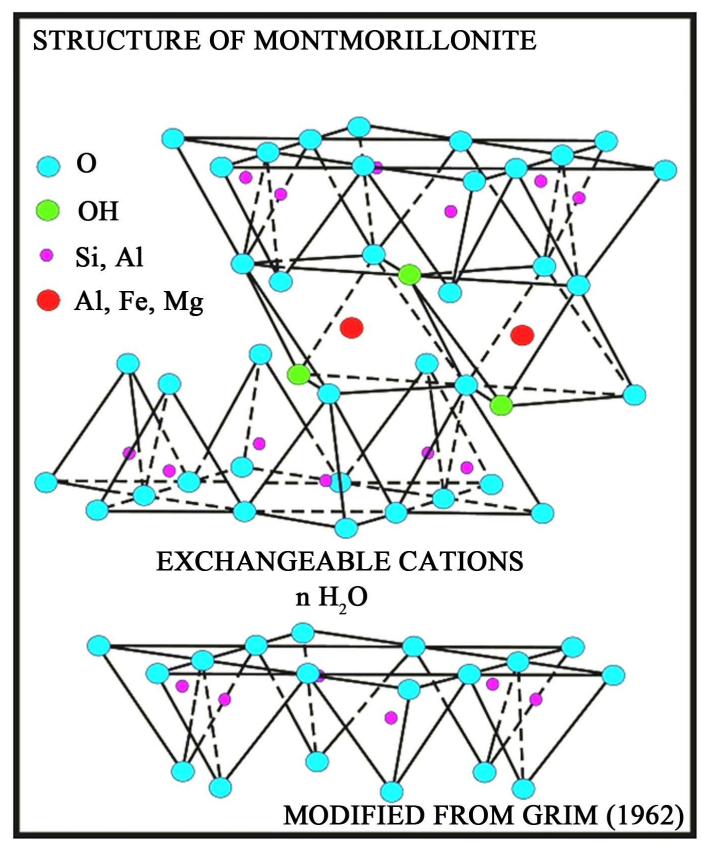

Figure 2. Representation of Montmorillonite clay [8].

The smectites are broadly dioctahedral smectites like montmorillonite and nontronite and the trioctahedral smectites like saponite and hectorite [1] [5]. Dioctahedral smectites consist of octahedra alumina placed between two silica tetrahedra sheets, trioctahedral smectites contain two octahedra alumina held between two silica tetrahedral sheets [5]. Commonly, kaolinite minerals contain silica 45\% - 56\%, alumina 9\% - 14\%, iron 0\% - 4\%, calcium or magnesium absent [7], yet smectites contain silica 20\% - 37\%, alumina $10 \%-25 \%$, iron 5\% - 16\%, calcium or magnesium 5\% - 15\%, sodium or potassium 5-15\% range [8] [9].

Geologically, bentonites transform to illites and kaolinites under hot wet conditions. However, hydrothermal alteration decreases the smectite content via replacement by kaolinite or halloysite and precipitation of various silica polymorphs, carbonates, sulphates and sulphides [13]. The factors favoring transformation of bentonite to illite are temperature [14] [15], pressure [16], potassium availability [17], pore fluid chemistry [18] and smectite composition [19]. The transformation of bentonite to illite leads to formation of quartz, chlorite and/or kaolinite by products [15]. The abundance of chlorite products depends on potassium availability in the bentonite undergoing diagenesis [20]. Kaolinite formation from a bentonite depends on the potassium ion/hydrogen ion activity ratio of the fluid. It has been shown that growth of illite-smectite particles might be controlled by Oswald ripening, characterized by dissolution of unstable particles followed by growth of stable particles [21]-[23]. While alteration of volcanic ash and basic tuffs in ultra basic conditions gives bentonites and zeolites [24]; diagenesis of granite and granitoids and acid tuffs gives kaolinites and quartz [25].

Diagenesis refers to the process and the changes (usually excluding cation exchange) that take place in sediments after deposition [26]. The definitions of diagenesis process vary widely over which changes and what part (or all) of the time between the transportation of the sediment and the time that sediment (ary rock) is studied should be included in daigenesis [26]. However, different authors favored the alternative explanations to account for many clay mineral distributions that were previously interpreted as representing changes in clay minerals in both recent sediments, and which were referred to diagenesis [27].

Kaolinites may form at the expense of granitoids, mainly granite rocks by means of in-situ alteration of feldspars on acid igneous rocks; hydrothermal alteration in hot wet climate of granite, quartz diorites, granodiorites, and rhyolites; and/or deuteric alteration of igneous materials involving reactions of vapors and gases with igneous mass [24]. Many bentonite deposits are formed by in-situ alteration of airborne and water transported volcanic ash in shallow lake and seawater [28]-[30]. Primary bentonites formed by in-situ hydrothermal alteration of ultra-basic volcanic glass, ash or feldspar [24] and both smectite and kaolinite rich clays can result from tropical weathering and the acid or basic nature of the environment is the determining factor for the clay type formed [31]. 
Some Central Uganda clays have been excavated, analyzed and classified; kaolinite deposits were found at Namasera Hills, Kajansi, Katiko, Kitetika, and Ntawo [32]-[34]; The kaolinitised basement rock near Mbale and Mutaka used by Tororo cement works is hydrothermal clay which includes 65\% kaolin [35]. Smectite-rich clays are expected to occur in the Karamoja pitch-black soils in the North Eastern Uganda [24]. X-ray diffraction, infrared, thermal differential analyses have been used to identify different clay minerals [3] [13] [36]-[39].

\section{Objective of Study}

To determine the elemental and mineral compositions of some selected clays of Uganda in order to establish their geological origin.

\section{Sampling Methods}

Samples of clay were collected from volcanic and non-volcanic areas in Central and Eastern Uganda. The clays were dug from virgin mines except for Kajansi, Seeta, Budadiri and Lwanda where clay mines were operational. The samples were collected at depths in range of $35-150 \mathrm{~cm}$ from the surface to reduce the effect of weathering and contamination.

\subsection{Sampling}

Clay samples were collected from:

a) Samples of clay were mined from Kajansi, Seeta, Lwanda, Nakawa, Kawuku, Umatengah, Chodah, located in non-volcanic areas of Uganda;

b) Samples of clay were mined from Mutufu, Budadiri, Siron and Chelel in areas of past volcanicity of Eastern Uganda near Mount Elgon.

\subsection{Sample Preparation}

\section{Preparation of Clays}

Raw samples of clays were separately soaked in distilled water, sieved to pass through a mesh $5.3 \times 10^{-4} \mathrm{~m}$ diameter, dried at $105^{\circ} \mathrm{C}$ and ground to powder using a rolling mill. The clay powders were stored for future use in desiccators.

\subsection{Experimental}

\subsubsection{Elemental Analysis of Clays}

The chemical analyses of elements like aluminium, iron, calcium, sodium and potassium in clays were carried out three times for every selected sample used in the study and done by decomposition using sodium carbonate fusion method [40] in platinum crucibles. Silica was determined by gravimetric analysis and the other elements were analyzed using the Perkin-Elmer 3030 model Atomic absorption spectrometer after dissolution of the sample in the hydrofluoric acid-perchloric acid digestion mixture.

\subsubsection{X-Ray Diffraction Analyses}

The mineralogy of clays was determined using X-ray Powder diffraction (Philips diffractometer with PW1710 control unit operating at $40 \mathrm{kV}$ and $30 \mathrm{~mA}$ using the Ni-filtered $\mathrm{Cu} \mathrm{K}_{\alpha}$ radiation). The diffractograms were automatically matched with JCPDS-cards in the computerized XRD CD-rom. Bulk mineralogy was studied with randomly oriented air-dried samples [41].

\subsubsection{Infrared Spectroscopic Studies}

The clay powder ( $3 \mathrm{mg}, 0.01 \mathrm{mmol}$ ) was mixed with $\mathrm{KBr}(100 \mathrm{mg}, 0.08 \mathrm{mmol})$ ground to powder and pressed into discs. The infrared spectra were run using the KBr discs using B10RD FT540 Fourier Transform IR spectrometer in the frequency range of $3700-400 \mathrm{~cm}^{-1}$ [42].

\subsubsection{Differential Thermal Analysis of Clays (DTA)}

A sample of clay (0.5 g, $1.2 \mathrm{mmol})$ together with inert reference sample of calcined alumina (0.5 g, $5 \mathrm{mmol})$, 
were placed in nickel block cavities and heated in parallel to $1100^{\circ} \mathrm{C}$ at the rate of $12^{\circ} \mathrm{C}$ per minute. The changes in mass and temperature of the sample against the reference were recorded in a table and drawn in graph.

\section{Results and Discussion}

\subsection{Description of Clays}

14 samples of clay were collected from the regions containing mainly kaolinite and six samples from regions suspected to contain smectites. In all cases the clays were dug from virgin mines except for Kajansi, Seeta, Budadiri and Lwanda where clay mines were operational. The samples were collected at depths in range of 35 $150 \mathrm{~cm}$ from the surface to minimize the effect of weathering and contamination.

The clay deposits sampled were observed to be stratified and most of them are composite, containing more than one distinct kaolinite or smectite mineral in the different horizons (shown in Figure 3), having either different lithological characteristics or/and different color.

It has been observed that the upper horizon for clay deposits in Central Uganda is black due to presence of organic matter and humus presumably brought into the swamps by surface water wash off of the top soil up stream. The upper horizons of the stratigram for the clay deposits from region associated with magmatic volcanism (Figure 3(c)) is yellow or orange in color because it contains iron which became oxidised on exposure to air [37] [38] for a long time and clays from lower horizons are dark grey because iron compounds have not been oxidised to iron III or there are other minerals and metal ions.

The upper horizons in clays from non-volcanic deposits do not show the orange or brown color because rainwater and/or fulvic or humic acids [43] leach Iron (III) compounds. This is supported by the fact that the orange or brown strata in clay deposits in areas devoid of volcanism lie deeper in the clay horizons in which the natural acids have not penetrated (Figure 3(a) and Figure 3(b)). The sampled deposits of clay had defined upper boundaries, but their basement is not known with certainty as drilling to the base was not carried out and additionally all the clays studied had been transported to those valleys where they were sampled from.

The clay samples showed that alteration of the parent rock is complete. The geological and spatial characteristics indicated that the deposits were formed by alteration probably of quartz, quartz diorites, dickites in acid conditions for clays in horizons in Figure 3(a) and Figure 3(b). The clays in stratigram in Figure 3(c) have formed by alteration of granitoids, rhyolites, volcanic ash, and dickites in the ultra basic media. As clays formed in uphill rocky remains, the possibility of in-situ digenesis of all clays studied has been ruled out on the ground that all clays had been transported and were sampled from a river valleys or/and swamps.

All clays studied had high content of quartz and this leads to the conclusion that there is downward migration of quartz. The clays therefore had a high content of silica. The sample deposits of Kajansi, Kawuku, Lwanda, Kumi and Seeta formed principally from a crystalline basement of Precambrian gneiss, schist and/or granitized rock bases. Clay deposits in Chelel, Siron, Mutufu and Budadiri showed presence of smectites, feldspars and plagioclase which are clear cut indicators that they were formed from tertiary-quaternary volcanic ashes or glass and are therefore much younger than the rest of the clay samples studied.

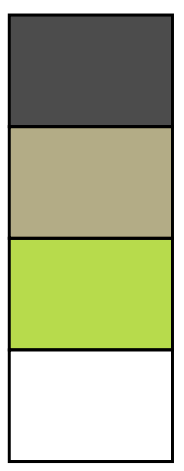

(a)

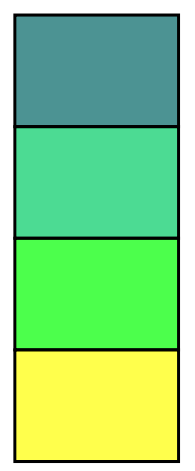

(b)

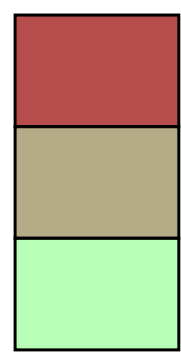

(c)

Figure 3. Representative clay horizons. Key: (a) Nakawa, Seta, Lwanda and Kajansi clays; (b) Umatengah, Chodah and Kumi clays; (c) Mutufu, Chelel, and Budadiri clay deposits. 


\subsection{Color of Clays}

Changes in colors of clays often suggest presence of characteristic elements, upon which prediction of surface and bleaching properties can be made. Records of colors of clays may serve as reference to nature of the environment from which the clay sediments were collected.

The clay deposits sampled exhibited different colors depicting differences in trace transition elements composition in the clays. The appearance of most clays depends on the quantity and oxidation state of iron and other transition elements present. While clays containing iron in oxidation state +3 are yellow or brown, green clays contain iron in oxidation state +2 . However, changes in color could also arise from presence of manganese and titanium compounds in different oxidation states [33] [44] [45].

The colors of selected clays observed in this study are shown in Table 1. The orange, brown and yellow clays were mined near the earth's surface and grey and white clays were mined from deeper deposits. The differently colored clay horizons were shown to contain various transition elements [33] [45]. The colors of the clays sampled varied from black to grey through orange in the deposits at Kajansi, Kawuku, Seeta, Lwanda, Chodah, Ngero, and Umatenga probably due to presence of iron and other colored metal compounds.

Weathering resulted in changes in mineral composition in these clays. There are two recognized categories of weathering processes: physical and chemical.

Physical weathering involves disintegration of rocks and minerals by a physical or mechanical process. Chemical weathering is chemical alteration or decomposition of rocks and minerals. However, both processes work together to break down rocks and minerals to smaller fragments of clay size or to clay minerals more stable near the earth's surface. Among the conditions present near the Earth's surface that are different from those deep within the earth are temperature, pressure, more free water and more free oxygen. Because of these differing conditions, minerals in rocks react with their new environment to produce new minerals that are stable under conditions near the surface.

Table 1. Clay color and pH.

\begin{tabular}{|c|c|c|c|}
\hline Clay & Source & Color & $\mathrm{pH} \pm 0.034$ \\
\hline A & Kajansi & Dark grey & 5.96 \\
\hline B1 & Seeta & Yellow-grey & 6.10 \\
\hline B2 & Seeta & Orange-brown & 4.95 \\
\hline $\mathrm{C}$ & Lwanda & Whitish-grey & 5.60 \\
\hline $\mathrm{D}$ & Nakawa & Reddish-brown & 5.75 \\
\hline $\mathrm{E}$ & Kawuku & Dark brown & 6.40 \\
\hline $\mathrm{F}$ & Umatenga & Grey-yellow & 6.30 \\
\hline G & Chodah & Grey-yellow & 6.80 \\
\hline $\mathrm{H}$ & Ngero & Dark-grey & 6.60 \\
\hline I1 & Budadiri & Dark brown & 5.60 \\
\hline $\mathrm{I} 2$ & Budadiri & Dark grey & 5.65 \\
\hline I3 & Budadiri & Dark grey & 6.50 \\
\hline $\mathrm{J} 1$ & Mutufu & Grey & 6.90 \\
\hline $\mathrm{J} 2$ & Mutufu & Dark grey & 8.40 \\
\hline K & Siron & Brown & 6.80 \\
\hline $\mathrm{L}$ & Chelel & Whitish grey & 7.90 \\
\hline
\end{tabular}


Minerals that are stable under conditions near the surface, in order of most stable to least stable, are oxides of iron and aluminium, quartz, clay minerals, muscovite, alkali feldspar, biotite, amphiboles, proxenes, calcium-rich plagioclase and olivine.

Clay minerals are an important group of minerals because they are among the most common products of chemical weathering, and thus are the main constituents of the fine-grained sedimentary rocks called mudrocks (including mudstones, claystones, and shales). In fact clay minerals make up about $40 \%$ of the minerals in sedimentary rocks. In addition, clay minerals are the main constituent of soils. Understanding of clay minerals is also important from an engineering point of view, as some minerals expand significantly when exposed to water. Clay minerals are used extensively in the ceramics industry and are thus important economic minerals.

Based on their structures and chemical compositions, the clay minerals can be divided into three main classes: kaolinites based on a structure similar to kaolinite; smectites based on a structure similar to pyrophyllite and illites based on a structure similar to muscovite. Each of these is formed under different environmental and chemical conditions. Kaolinite is formed by weathering or hydrothermal alteration of alumino-silicate minerals. Thus, rocks that are rich in feldspar commonly weather to kaolinite. In order to form, ions like sodium, potassium, calcium, magnesium and iron must first be leached away by the weathering or alteration process. This leaching is favored by acidic conditions (low pH). Granitic rocks, because they are rich in feldspar, are a common source for kaolinite. Halloysite, is also a kandite clay, with a structure similar to kaolinite. Kaolinite has the chemical formula- $\mathrm{Al}_{2} \mathrm{Si}_{2} \mathrm{O}_{5}(\mathrm{OH})_{4} \cdot 4 \mathrm{H}_{2} \mathrm{O}$. Kaolinite does not absorb water, does not expand when it comes in contact with water, so it is preferred for ceramics.

The smectite group of clays has a structure similar to that of pyrophyllite, but can also have significant amounts of magnesium and iron substituting into the octahedral layers. Thus, the smectites can be both dioctahedral and trioctahedral. The most important aspect of the smectite group is the ability for $\mathrm{H}_{2} \mathrm{O}$ molecules to be absorbed between the sheets, causing the volume of the minerals to increase when they come in contact with water, smectites are expanding clays with a general chemical formula, (1/2Ca, $\mathrm{Na})(\mathrm{Al}, \mathrm{Mg}, \mathrm{Fe})_{4}(\mathrm{Si}, \mathrm{Al})_{8} \mathrm{O}_{20}$ $(\mathrm{OH})_{4} \cdot \mathrm{nH}_{2} \mathrm{O}$. And montmorillonite is the commonest smectites and it is the main constituent of Bentonite, derived by weathering of volcanic ash. Montmorillonite can expand its original volume by several times when it comes in contact with water.

However, the kimolian white bentonites were found to have higher brightness and whiteness index values, and lower yellowness index and the variations in white color were inversely related to the abundance of iron oxides and anatase [46]. The occurrence of iron in the smectite structure and its oxidation state caused variations in color [46]. The presence of silica minerals is not an important factor affecting color, but is undesirable since it imparts high abrasiveness in commercial products [47].

The selected clay deposits at Siron, Budadiri, Mutufu and Chelel showed colors ranging from brown or orange through grey to white due to presence of iron in different oxidation states as well as difference in the mineralogical compositions in the different strata resulting from the levels of alteration and migration of silica through the mine. The clays from deposits at Kajansi, Seeta, Lwanda, Nakawa and Kawuku had pH values near 6 showing that they are acidic presumably as result of the natural acidity of the hydroxyl groups on silica sites [48].

The selected clay samples from Mutufu and Chelel had average $\mathrm{pH}$ ranging from 7.5 to $8.50 \pm 0.034$, due to the environment where they were mined was ultra alkaline. The alkalinity of the clay slurries is attributed to presence of alkali and alkaline earth metals whose silicates strongly hydrolyse raising the $\mathrm{pH}$ above 7 . This showed presence of excess alkali metals like sodium and potassium as well as K-feldspars in these clays. The pH of slurries for bentonites or montmorillonites was reported to lie in the range between 7.8 and 8.5 [49]-[52]. As the pH for Mutufu and Chelel clays were as high as those for bentonites from Egypt, Saudi Arabia and Wyoming (USA), it is possible that these clays have high smectite content.

As low pH of kaolinites is associated with presence of acidic water or ionisable hydroxyl groups on the surface of clays, it has been proposed that the slurries of kaolinites ionise. The $\mathrm{pH}$ of slurries of smectite-rich clays is greater than 7 due to hydrolysis of sodium or/and potassium silicates. The hydrolysis may be complete or partial. Therefore, the interlayer ions are structurally acting as counter ions to the silicate skeleton in nontronite.

\subsection{Mineralogy of Clays}

Clays are classified in two major groups: kaolinites and smectites [5]. It is essential to study their mineralogy before looking up their detailed physical, chemical, structural and surface properties because the properties of 
clays mainly depend on their mineralogical compositions. The presence of smectites in clays and clay minerals is an indication that the clay can be used as fullers or bleaching earths and presence of kaolinites gives chance to getting clays for ceramics and pottery works although even smectites can be used similarly.

The selected samples used in this study are broadly divided into smectites and kaolinites basing on mineral compositions. While kaolinites are clays containing kaolinite, halloysite, metahalloysite, quartz and illite as dominant minerals [53], smectites may contain phyllosilicates like nontronite, montmorillonite, plagioclase, feldspars, and illite as distinguished minerals [54] [55].

The selected clays from Budadiri, Chelel, Siron and Mutufu showed presence of quartz, nontronite, illite, plagioclase, feldspars and kaolinite showing that these clays were of the phyllosilicate (smectite) type and will probably show high bleaching tendencies because their surface properties will be modified by acid leaching very easily [56].

The clays studied showed different compositions of the minerals. Despite the efforts to eliminate sand stones and quartz through filtering, clay deposits at Kajansi, Kawuku, Seeta, Lwanda, Nakawa, Umatenga, Chodah, and Ngero had large quantities of quartz as shown in Table 2. The kaolin content of clay samples A, $B_{1}, B_{2}, C, D, E, F$, $G$ and $H$ mined from regions devoid of volcanic margins is higher than that for clay samples $I_{1}, I_{2}, I_{3}, J_{1}, J_{2}, K$ and $\mathrm{L}$ mined from regions associated with past volcanic activity because of differences in their digenetic paths and parent rock compositions.

The selected clays used in this study showed presence of quartz, kaolinite, illite, halloysite and metahalloysite in clays sampled from Kumi, Ngero, Nakawa, Kawuku, Seeta and Chodah showed that these clays formed from granite in acidic medium. This showed that these clays differ from those formed from volcanic sediments and have different structural, chemical, mineralogical, surface and bleaching properties, age and diagenesis [54].

The mineralogical compositions above have been determined using the Reynold's semi-quantitative method [33] [40] [54]. These results reveal that the dominant clay mineral in the clay deposits at Kajansi, Kawuku, Lwanda, Nakawa, Chodah, Umatengah, Ngero and Seeta is kaolinite and this coincides with the findings about the Kajansi, Ntawo and Kitetikka clays mined from Central Uganda [33] [57]. It is not surprising that clays from these areas have been used for pottery, ceramic, bricks and tiles.

\begin{tabular}{|c|c|c|c|c|c|c|c|}
\hline Sample & Kaolin \% & Quartz \% & Halloysite \% & Smectite \% & Illite \% & Feldspars \% & Plagioclase \% \\
\hline A & 31.3 & 50.0 & 6.2 & 6.3 & ND & 6.2 & ND \\
\hline $\mathrm{B}_{1}$ & 37.5 & 37.5 & 25.0 & ND & ND & ND & ND \\
\hline $\mathrm{B}_{2}$ & 40.0 & 53.3 & 6.6 & ND & ND & ND & ND \\
\hline $\mathrm{C}$ & 40.0 & $26 . .3$ & 6.6 & ND & 26.7 & ND & ND \\
\hline $\mathrm{D}$ & 53.3 & 40.0 & 6.6 & ND & ND & ND & ND \\
\hline $\mathrm{E}$ & 40.0 & 53.5 & 6.5 & ND & ND & ND & ND \\
\hline $\mathrm{F}$ & 36.4 & 36.4 & 18.2 & 4.5 & ND & 4.5 & ND \\
\hline G & 47.1 & 47.1 & 5.8 & ND & ND & ND & ND \\
\hline $\mathrm{H}$ & 37.5 & 37.5 & 25.0 & ND & ND & ND & ND \\
\hline $\mathrm{I}_{1}$ & 23.5 & 23.5 & ND & 6.0 & ND & 23.5 & 23.5 \\
\hline $\mathrm{I}_{2}$ & 25.0 & 25.0 & ND & ND & ND & 25.0 & 25.0 \\
\hline $\mathrm{I}_{3}$ & 23.5 & 23.5 & ND & ND & 6.00 & 23.5 & 23.5 \\
\hline $\mathrm{J}_{1}$ & 23.5 & 23.5 & ND & 5.6 & ND & 23.5 & 23.0 \\
\hline $\mathrm{J}_{2}$ & 7.7 & 15.4 & ND & 46.2 & ND & 30.5 & ND \\
\hline $\mathrm{K}$ & 23.5 & 23.5 & ND & 6.0 & ND & 23.5 & 23.5 \\
\hline L & 7.7 & 10.4 & ND & 50.0 & ND & 30.0 & ND \\
\hline
\end{tabular}

Key: ND refers to not detected as the peak for the mineral was very low or invisible on the X-ray diffractograms as it was less than $1 \%$; Clay samples designated as A, B, C, D, E, F, G, H, I, J, K and L were selected from the respective sediments from Kajansi, Seeta, Lwanda, Nakawa, Kawuku, Umatengah, Choha, Ngero, Budadiri, Mutufu, Siron and Chelel. 
The dominant clay mineral in clay deposits at Budadiri, Chelel, Siron and Mutufu is nontronite, a smectite and this coincides with studies on clays formed from volcanic sediments. The presence of bentonite among volcanic sediments all over the world was discussed by many authors [52] [55] [58] [59]. The main smectite mineral present in the Budadiri, Chelel, Mutufu and Siron clay deposits is nontronite which is a dioctahedral clay as shown by the X-ray diffractograms. Tri-octahedral smectites are virtually absent in these smectites, a sign showing that these clays must show reduced bleaching capacity as compared to bentonites. The Kajansi, Kawuku, Lwanda, Nakawa, Chodah, Umatengah, Ngero and Seeta clays are highly deficient in di- and/or tri-octahedral smectites, implying their bleaching capability is expected to be minimal even when acid-activated [60].

The high abundance of quartz in all clay deposits sampled showed that the clays must have high silica content, and are bound to be strongly acidic as the silica provides several sites for the hydroxyl groups or water molecules to bind. Presence of high silica content in the clays does not serve as evidence for the migration of silica in the mines [61]. However, the high abundance of silica in Aegean clays (Greece) was advanced to show the downward migration of silica in the mines [62] [63].

Feldspars are rare among Kajansi, Kawuku, Nakawa, Chodah, Umatengah, Lwanda, Ngero and Seeta deposits, showing that the weathering process is complete or near complete. The abundancy of quartz in these clays is an indication of the remains of the unaltered gneiss-granitoids parent rock [64]. The abundance of feldspars and plagioclase in the clays from Budadiri, Chelel, Siron and Mutufu is an indication of the partial weathering of the parent rock and further reveals that these clays are younger than those from Kajansi, Kumi, Chodah, Umatengah, Kawuku and Seeta. As the smectite/kaolinite ratio for Kumi, Seeta, Umatengah, Kawuku, Nakawa clay deposits is $0: 1$ yet that for the Kajansi clay deposits is 1:5, it can be asserted that weathering in these deposits took place in acidic media and the formation of smectites may have occurred independently of diagenesis. Evidence for the strong acidity of the environment is shown by the low $\mathrm{pH}$ of the clays from these deposits caused by adsorbed water and hydroxyl groups on silica. Since the smectite/kaolinite ratios for Budadiri, Chelel, Mutufu and Siron deposits varied between 1:4 and 1:0.13, it showed that weathering took place in alkaline medium and kaolinitization of these clay deposits may have been a separate process [63]. The evidence for the strong alkalinity of the environment where smectites are mined is shown by the high $\mathrm{pH}$ of the clay solutions made by suspending these clays in distilled water.

The bentonite deposits of Kimolos Island, Aegean, Greece were investigated in order to determine their physical and chemical properties [64] by testing for swelling capacity, $\mathrm{pH}$, rheological properties, green and dry compression strength. These properties were influenced by the smectite content and the degree of disaggregation of the smectite quasi-crystals due to the nature of the interlayer cation, the presence of mordenite, undevitrified glass shards and the degree of the oxidation of iron. The mineralogical compositions of clays give hint on the structural, surface and bleaching properties of the clays. Clays rich in both di- and tri-octahedral smectites give better bleaching earths than those deficient in smectites. The world over, clays with high smectite content (bentonites and montmorillonites) are used in manufacture of bleaching and cracking catalysts, because once leached they develop higher acidity than kaolinites [52] [56] [58] [65].

In this study, it has been found that kaolinite-rich clays from Seeta, Nakawa, Kawuku, Kajansi, Chodah, Lwanda and Umatengahmineralogically contain between 31\% and 53\% kaolinite, 5.8\% and $18.2 \%$ halloysite and this has been used to propose that the structures of these clays is an amalgamation of kaolinite and halloysite structures. For the smectite-rich clays selected from Chelel, Mutufu, Budadiri and Siron contained clay minerals in the ranges of $46 \%$ - 50\% nontronite, $23 \%$ - 30.5\% feldspars and $1 \%$ - $25 \%$ plagioclase, we can propose that these clays have a di-octahedral structure [9] and will show enhanced surface properties when acid-leached.

\subsection{Elemental Analyses}

Elemental analyses of clays have always revealed the class of alumino-silicates to which the analyzed material belongs [9] [65]. For example, smectites commonly give different elemental compositions from kaolinites. In a study involving clays, it is important to establish the elemental constitution of the solid because surface and bleaching properties of clays and clay material depend on the elements present. The averaged data obtained in the elemental analyses of selected clays are in Table 3.

The elements present in clays have been presented as relative percentages of the elements expressed as oxides in the entire sample in Table 3. The selected clay deposits at Kajansi, Kawuku, Seeta, Lwanda, and Umatengah had more than 50\% silicon dioxide yet Budadiri, Mutufu, and Chelel clay had less than $50 \%$ silicon dioxide 
Table 3. Average elemental composition of selected clays.

\begin{tabular}{ccccccccccc}
\hline Clay sample & $\mathrm{A}$ & $\mathrm{B}_{1}$ & $\mathrm{E}$ & $\mathrm{F}$ & $\mathrm{H}$ & $\mathrm{I}_{1}$ & $\mathrm{I}_{2}$ & $\mathrm{~J}$ & $\mathrm{~K}$ & $\mathrm{~L}$ \\
\hline $\mathrm{LOI}$ & 9.3 & 4.5 & 5.0 & 9.0 & 7.2 & 8.0 & 9.0 & 8.2 & 9.7 & 9.9 \\
$\mathrm{SiO}_{2}$ & 49.4 & 63.1 & 65.0 & 71.0 & 66.0 & 55 & 46.0 & 48.0 & 45.0 & 44.3 \\
$\mathrm{Al}_{2} \mathrm{O}_{3}$ & 20.1 & 10.5 & 11.1 & 8.4 & 9.0 & 15.0 & 12.0 & 13.0 & 18.3 & 19.4 \\
$\mathrm{Fe}_{2} \mathrm{O}_{3}$ & 8.0 & 1.5 & 1.4 & 1.8 & 3.5 & 5.7 & 6.0 & 4.1 & 5.7 & 6.2 \\
$\mathrm{CaO}$ & 0.2 & 0.1 & 0.1 & $\mathrm{ND}$ & $\mathrm{ND}$ & 2.0 & 2.1 & 2.0 & 2.3 & 2.4 \\
$\mathrm{Na}_{2} \mathrm{O}$ & 0.1 & 0.1 & 0.1 & $\mathrm{ND}$ & 0.1 & 3.0 & 3.0 & 2.0 & 3.5 & 3.4 \\
$\mathrm{~K}_{2} \mathrm{O}$ & 0.3 & 0.4 & 0.1 & $\mathrm{ND}$ & $\mathrm{ND}$ & 1.0 & 1.2 & 2.1 & 2.4 & 2.6 \\
$\mathrm{Total}$ & 87.4 & 80.2 & 82.8 & 83.0 & 85.8 & 89.7 & 79.3 & 79.4 & 86.9 & 88.2 \\
\hline
\end{tabular}

Key: LOI is loss on ignition, signifying an estimate of matter lost when the clay was heated. ND is not detected. Readability was 0.045. A, B, E, F, H, I, $\mathrm{J}$, K and L were respectively Kajansi clay, Seeta clay, Kawuku clay, Chodah clay, Umatengah clay, Budadiri hill clay, Budadiri river valley clay, Mutufu clay, Siron clay and Chelel clay.

showing that volcanic clays of Mutufu, Budadiri and Chelel should be less acidic than clays from Kawuku, Kajansi, Umatengah or Lwanda as the high silica/quartz content gives higher chances of exposing hydroxyl groups and adsorption of water on silica which causes the clays to be acidic. The differences in silica content indicated that the parent rocks in these sets of deposits are very different, silica readily dissolves in alkaline medium but does not in acidic medium. The Kajansi, Kawuku, Umatengah, Lwanda clays formed from acid igneous quartz diorites in a similar way to the Singo granite [25] [66] [67]. The volcanic clays formed from alkaline intrusive granitoids in ultra basic media, contain less silica as it dissolved in alkaline medium.

Similarly, the data adduced in the study on clays from the Ntawo, Kajansi, and Kitetikka valleys reveal that the valleys are filled with quaternary to recent alluvial and lacustrine sands, silt, and gravel, which are derived from underlying meta-sediments of Buganda-Toro system and granitoid rocks of the basement and the clays therein are composed of sandy sediment, with kaolinite, chlorite, smectite, quartz, feldspars and calcite as minerals that could be observed using X-ray crystallography [33]. Clay deposits in Central Uganda have been shown to averagely contain $\approx 59 \% \pm 0.045 \%$ silicon dioxide, $20 \% \pm 0.045 \%$ aluminium oxide, $9 \% \pm 0.045 \%$ iron oxide and other elements [68].

Similarly, the clays from Kajansi, Kawuku, Seeta, Umatengah and Kumi have been found to contain these elements in nearly the same proportions. This showed that the parent rock was quartz diorites which weathered in acidic medium. However, clays from magmatic sediments in oceans were reported to contain major elements with relatively high magnesium oxide, ranging from $23.9 \%$ to $40.4 \%$ and low silicon dioxide and aluminium oxide, ranging from $12.8 \%$ to $29.0 \%$ [69] and their data confirms the data that we have adduced in this study on clays from Mutufu, Chelel, Budadiri and Siron which are associated with volcanic margins of Mountain Elgon.

The loss on ignition of the selected clays used in this study lie in the range of $6 \%-10 \%$, an indication that heating clays to $105^{\circ} \mathrm{C}$ results in loss of structural water from the clay [70]. The reactions occurring in the clay materials include dehydration and dehydroxylation of soil used.

Apart from clay deposits at Kajansi, Mutufu, Budadiri, Chelel and Siron, all other deposits had higher silicon dioxide content revealing the diagenetic paths for these clays are different [25]. The Kajansi, Kawuku, Seeta, Chodah and Umatengah clays showed relative quantities of element in the same ranges found for Kitetikka, Katiko, Kajansi and Ntawo clays [33] because of similarity in the parent rock which weathered to give the clays. The presence of higher concentrations of iron oxides and/or aluminium oxide in Budadiri, Kajansi, Mutufu, Chelel and Siron deposits than all other deposits sampled, may be responsible for their higher surface acidities and bleaching capacities when acid-leached than other clays studied.

The percentages of iron, aluminium and silicon among bentonites worldwide are approximately $11 \%, 18 \%$, and $60 \%$ respectively. Basing on this, clays from Mutufu, Budadiri and Chelel ressemble bentonites can serve as replacements for commercial bleaching earths and cracking catalysts. On the basis of relative percentages of aluminium, silicon and alkaline metals or alkaline earth metals [9], the clays studied have been found to satisfy the formulae in Table 4. As shown, most clay samples had quartz or silicon dioxide as remains granite which 
Table 4. Formulae and names of selected clays.

\begin{tabular}{|c|c|c|c|}
\hline Clay sample & Clay formula & Name & Reference \\
\hline A & $\begin{array}{c}\mathrm{Al}_{2} \mathrm{Si}_{2} \mathrm{O}_{5}(\mathrm{OH})_{4} \text { mixed with } \mathrm{Ca}_{5}\left(\mathrm{Si}_{7} \mathrm{Al}_{8} \mathrm{Fe}_{2}\right)\left(\mathrm{Fe}_{3.5} \mathrm{Al}_{4} \mathrm{Mg}_{.1}\right) \mathrm{O}_{20}(\mathrm{OH})_{4} \\
\text { and silica } \mathrm{SiO}_{2}\end{array}$ & Kaolinite and nontronite & {$[6]$} \\
\hline $\mathrm{B}_{1}$ & $\mathrm{Al}_{2} \mathrm{Si}_{2} \mathrm{O}_{5}(\mathrm{OH})_{4}$ mixed with $\mathrm{SiO}_{2}$ & Kaolinite and quartz or silica & {$[6]$} \\
\hline $\mathrm{E}$ & $\mathrm{Al}_{2} \mathrm{Si}_{2} \mathrm{O}_{5}(\mathrm{OH})_{4}$ mixed with $\mathrm{SiO}_{2}$ & Kaolinite and quartz or silica & {$[6]$} \\
\hline $\mathrm{F}$ & $\mathrm{Al}_{2} \mathrm{Si}_{2} \mathrm{O}_{5}(\mathrm{OH})_{4}$ mixed with $\mathrm{SiO}_{2}$ & Kaolinite and quartz & {$[6]$} \\
\hline $\mathrm{I}_{1}$ & $\mathrm{Ca}_{5}\left(\mathrm{Si}_{7} \mathrm{Al}_{8} \mathrm{Fe}_{2}\right)\left(\mathrm{Fe}_{3.5} \mathrm{Al}_{4} \mathrm{Mg}_{1}\right) \mathrm{O}_{20}(\mathrm{OH})_{4}$ with $\mathrm{SiO}_{2}$ & Nontronite and quartz & [9] \\
\hline $\mathrm{I}_{2}$ & $\mathrm{Ca}_{.5}\left(\mathrm{Si}_{7} \mathrm{Al}_{8} \mathrm{Fe}_{2}\right)\left(\mathrm{Fe}_{3.5} \mathrm{Al}_{4} \mathrm{Mg}_{1}\right) \mathrm{O}_{20}(\mathrm{OH})_{4}$ with $\mathrm{SiO}_{2}$ & Nontronite and quartz & [9] \\
\hline $\mathrm{J}$ & $\mathrm{Al}_{2} \mathrm{Si}_{2} \mathrm{O}_{5}(\mathrm{OH})_{4}$. & Halloysite & {$[6]$} \\
\hline $\mathrm{K}$ & $\begin{array}{l}(1 / 2 \mathrm{Ca}, \mathrm{Na})_{0.33}\left(\mathrm{Mg}, \mathrm{Fe}^{+2}\right)_{3}(\mathrm{Si}, \mathrm{Al})_{4} \mathrm{O}_{10}(\mathrm{OH})_{2} \cdot 4 \mathrm{H}_{2} \mathrm{O} \\
\text { and } \mathrm{Na}_{0.3}\left(\mathrm{Fe}_{.2}\right) \mathrm{Si}_{4} \mathrm{O}_{10}(\mathrm{OH})_{2} 4 \mathrm{H}_{2} \mathrm{O}\end{array}$ & Montmorillonite and nontronite & [9] \\
\hline $\mathrm{L}$ & $\begin{array}{c}(1 / 2 \mathrm{Ca}, \mathrm{Na})_{0.33}\left(\mathrm{Mg}, \mathrm{Fe}^{+2}\right)_{3}(\mathrm{Si}, \mathrm{Al})_{4} \mathrm{O}_{10}(\mathrm{OH})_{2} \cdot 4 \mathrm{H}_{2} \mathrm{O} 4 \mathrm{H}_{2} \mathrm{O} \\
\text { and } \mathrm{Na}_{0.3}\left(\mathrm{Fe}_{2}\right) \mathrm{Si}_{4} \mathrm{O}_{10}(\mathrm{OH})_{2} 4 \mathrm{H}_{2} \mathrm{O}\end{array}$ & Montmorillonite and nontronite & [9] \\
\hline
\end{tabular}

Key: Samples A, B, E, F, H, I, J1,J2, K and L were respectively Kajansi clay, Seeta clay, Kawuku clay, Chodah clay, Umatengah clay, Budadiri hill clay, Budadiri river valley clay, Mutufu clay, Siron clay and Chelel clay.

altered to give the clay; volcanic clay sediments I, $\mathrm{K}$ and L had smectites yet non-volcanic clay sediments sampled as $\mathrm{A}, \mathrm{B}, \mathrm{E}, \mathrm{F}$ and $\mathrm{J}$ had kaolinites as clay mineral in mixture with quartz. Basing on the clay minerals present in the samples, it can be concluded that kaolinites occur in Central Uganda and Kumi as these areas were devoid of volcanism. The smectites occur in volcanic sediments of Sironko and Kapchorwa because the areas lie on the foothills of Mountain Elgon, a well known volcanic mountain.

\subsection{Infra Red (IR) Spectroscopy}

IR studies have been used to identify smectites because they show broad absorption band at $3600 \mathrm{~cm}^{-1}$ due to OH, $3454 \mathrm{~cm}^{-1}$ due to inter layer water, $1664 \mathrm{~cm}^{-1}$ due to deformational vibration in the HOH group, at 1042 and 798 $\mathrm{cm}^{-1}$ due to Si-O vibration, the bands at 526 and $466 \mathrm{~cm}^{-1}$ show presence of Si-O-Al and Si-O-Si deformation vibrations respectively [62]. IR studies on clays help to identify presence of characterizing groups in smectites and kaolinites. So knowledge of behaviour of clays in the IR region of the electromagnetic spectrum goes a long way to establish the identities of groups of ions in the clays. Different groups show different stretching modes at different frequencies in the infra red region of the electromagnetic spectrum. The IR absorption spectrum for the smectite-rich natural clay was shown to have absorption band at $3640 \mathrm{~cm}^{-1}$ attributed to stretching vibrations of the OH group while that at $3454 \mathrm{~cm}^{-1}$, the presence of interlayer water. The amount of adsorbed water in clays is related to the deformation vibrations of the H-O-H group $\left(1664 \mathrm{~cm}^{-1}\right)$. The bands at 1042 and $798 \mathrm{~cm}^{-1}$ are attributed to Si-O stretching vibrations [13]. The bands at 526 and $466 \mathrm{~cm}^{-1}$ correspond to deformation vibrations of Si-O-Al and Si-O-Si, respectively [71].

The clay deposits at Kajansi, Kawuku, Seeta, Umatengah, Chodah, Nakawa and Ngero showed strongly resembling infrared (IR) spectra (shown in Figures 4(a)-(c)) due to presence of identical groups of ions or minerals.

The band at $1040 \mathrm{~cm}^{-1}$ is assigned to (Si-O). The band at $3454 \mathrm{~cm}^{-1}$ is due to adsorbed water, and that at 3640 $\mathrm{cm}^{-1}$ is due to (Al-Al-OH, Mg-OH-Al). The broadening of the absorption bands in the kaolinite-rich clays indicates high acidity of the clays even when they are air dried. Kaolinite clays contain protonated water and hydroxyl groups on silica in their crystal lattices and their absorption bands tend to be broader. The absorption bands at 918 and $879 \mathrm{~cm}^{-1}$ in Figures 4(c)-(d) in the representative spectra for the clay deposits at Mutufu, Chelel, Budadiri and Siron characteristically contain smectites and band at $800 \mathrm{~cm}^{-1}$ is obscured by Si-O mode which is broadened. These bands are due to the bending mode of $\mathrm{Al}-\mathrm{Fe}-\mathrm{OH}$ bonds and smectites are also expected to show absorption bands at $845 \mathrm{~cm}^{-1}$ [13]. Some absorption peaks were not well resolved because the different clay minerals were mixed together.

The IR spectra for the kaolinite-rich clays from Kajansi, Kumi, Nakawa, Kawuku, Seeta, Chodah and Umatengah showed peaks due to hydroxyl stretch at $3600 \mathrm{~cm}^{-1}$, Al-OH at $3490 \mathrm{~cm}^{-1}, \mathrm{H}-\mathrm{O}-\mathrm{H}$ stretch at $1640 \mathrm{~cm}^{-1}$, 


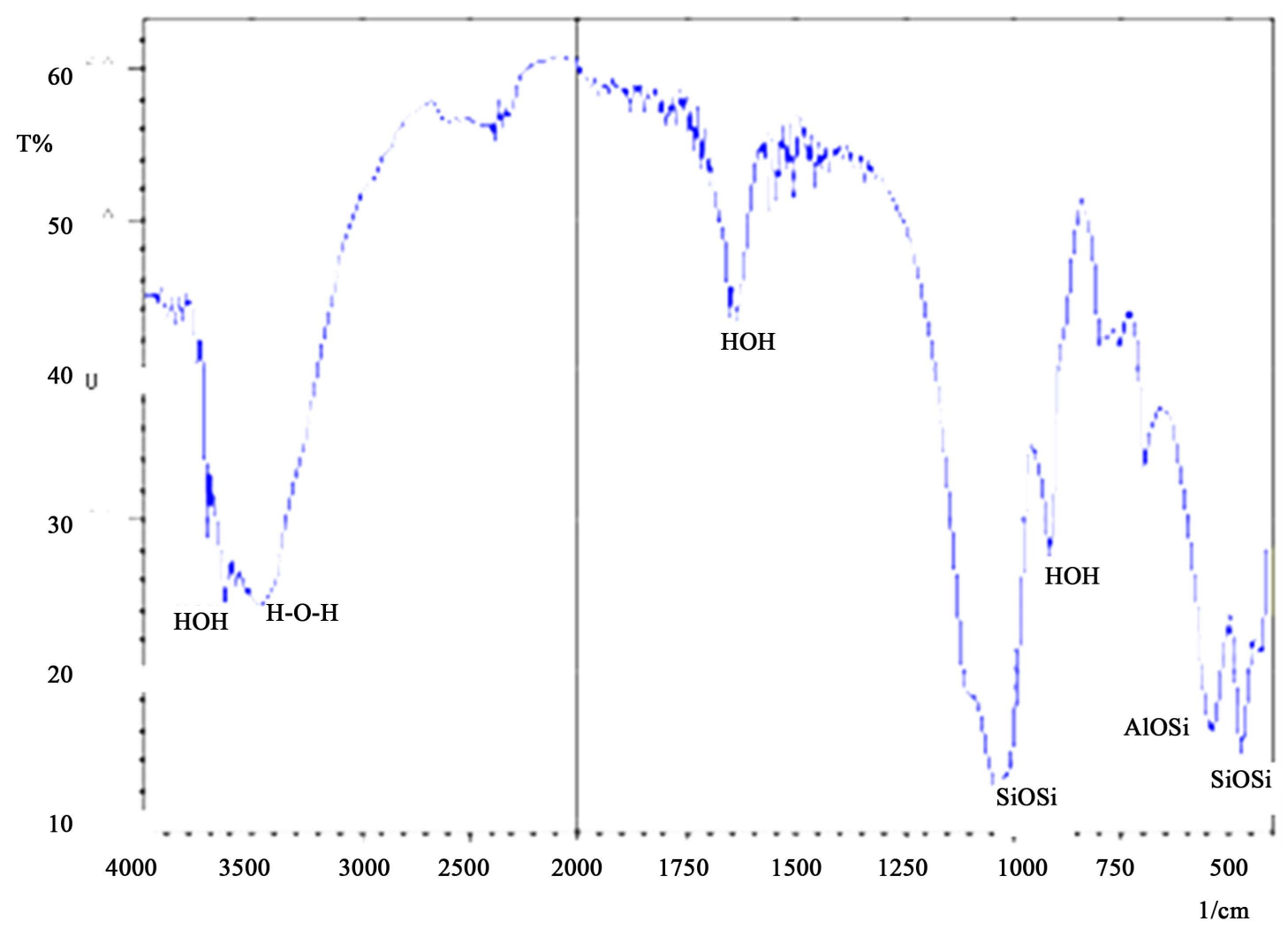

(a)

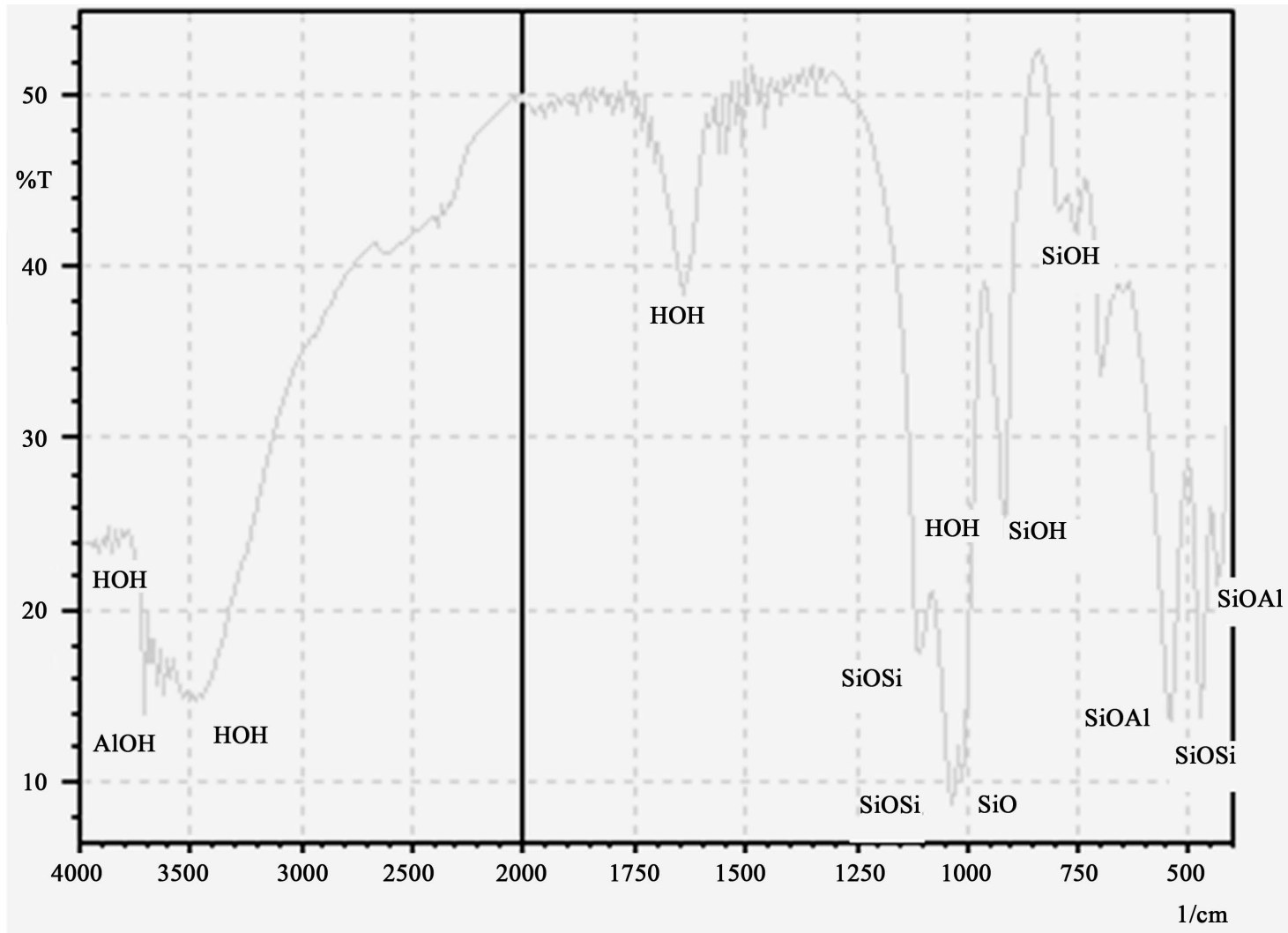

(b) 


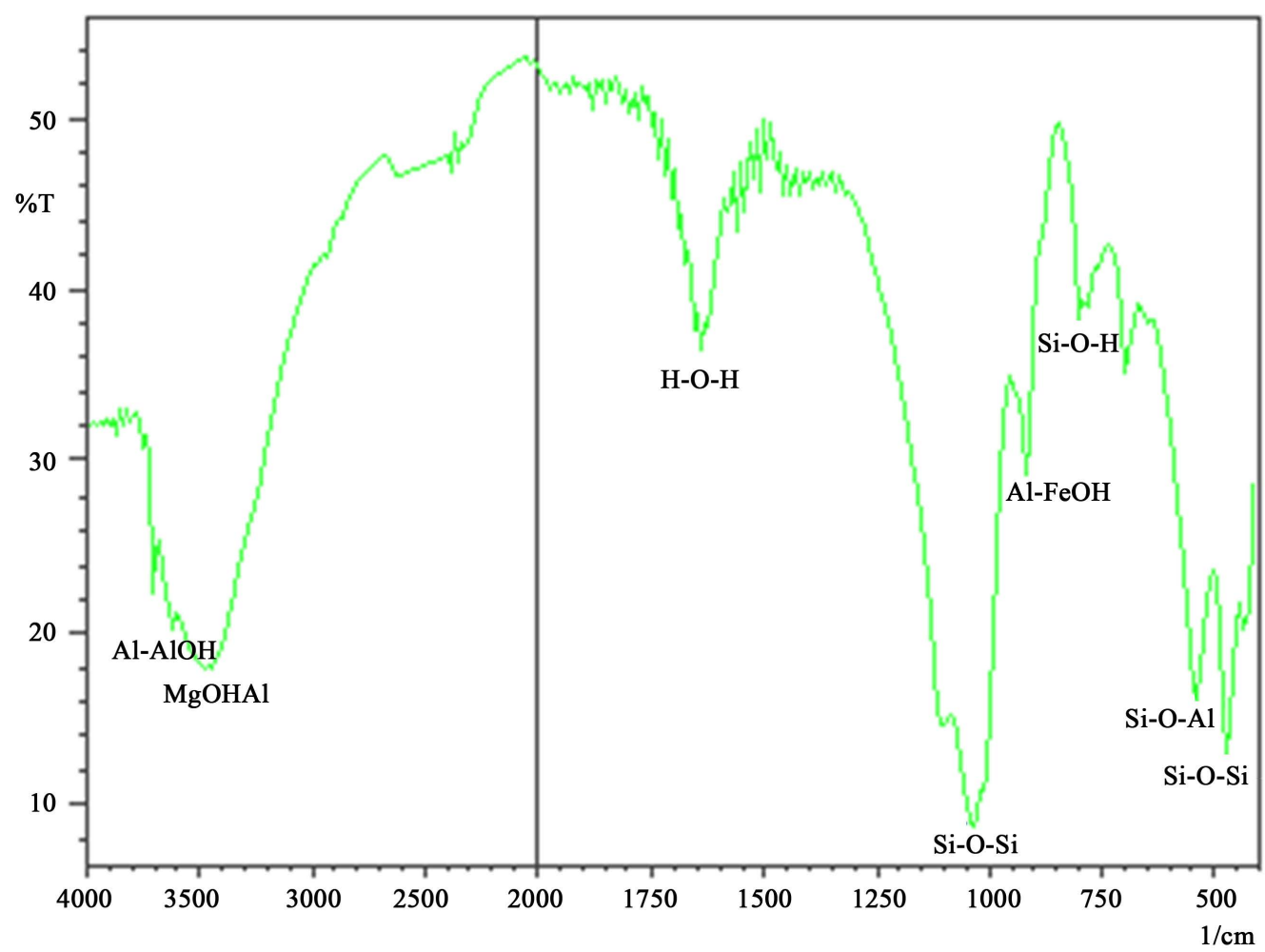

(c)

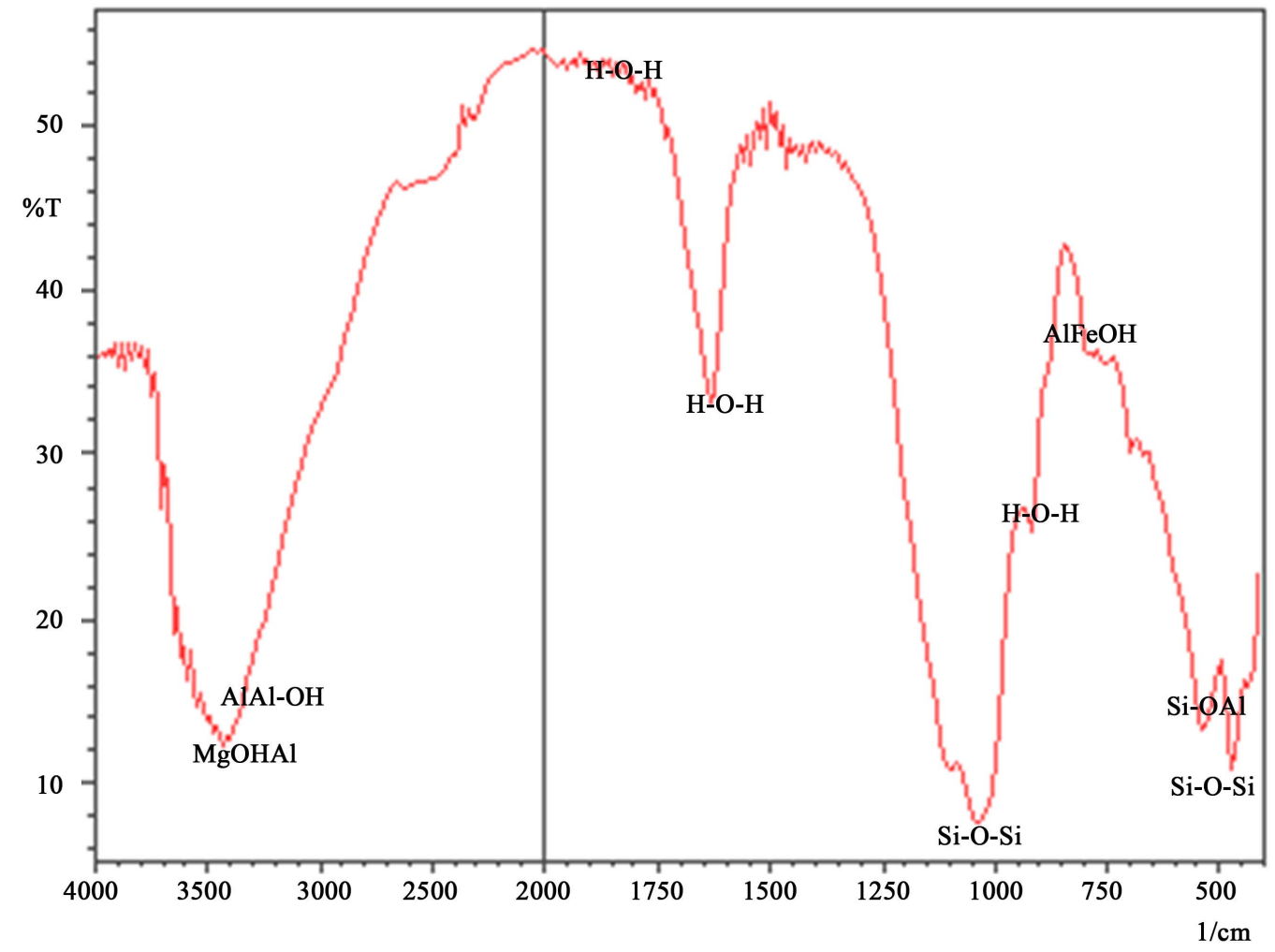

(d)

Figure 4. a) IR spectrum for Kajansi clay (kaolinite-rich clay); b) IR spectrum for Kumi clay ( kaolinite-rich clay); c) IR spectrum for Mutufu clay (smectite-rich clay); d) IR spectrum for Chelel clay (smectite-rich clay). 
Si-O-Si stretch at $1100 \mathrm{~cm}^{-1}$, Si-OH stretch at $900 \mathrm{~cm}^{-1}$, Si-O-Al stretch at $550 \mathrm{~cm}^{-1}$ and Si-O-Al at $470 \mathrm{~cm}^{-1}$, it has been proposed that these clays conform to the structure of kaolinite and halloysite [72].

The IR spectra for smectite-rich clays selected from Mutufu, Budadiri, Siron and Chelel showed peaks due to $\mathrm{Mg}-\mathrm{OH}-\mathrm{Al}$ stretch at $3490 \mathrm{~cm}^{-1}$, Al-Al-OH stretch at $3480 \mathrm{~cm}^{-1}, \mathrm{H}-\mathrm{O}-\mathrm{H}$ at $1800 \mathrm{~cm}^{-1}$ and $1620 \mathrm{~cm}^{-1}$, Si-O-Si at $1100 \mathrm{~cm}^{-1}$, Al-Fe-OH at $800 \mathrm{~cm}^{-1}$, Si-O-Al at $600 \mathrm{~cm}^{-1}$ and Si-O-Si at $490 \mathrm{~cm}^{-1}$ showed that these clays conform to the structure of montmorillonite [8].

\subsection{X-Ray Diffraction (XRD) Analyses}

Powder XRD diffractograms were used to characterize minerals and elements present in solids. Clay powders can be distinguished in two broad classes: smectites and kaolinites basing on XRD patterns. XRD analyses therefore form a core component in elucidating clay structures [40]. The differences in clay structures may give hints on structural, bleaching and surface properties of clays and clay minerals. The XRD diffractograms (Figures 5(a)-(c)) of the natural bentonite showed the presence of smectite (S), kaolinite (K), gypsum (G), and quartz (Q) is evident in the figure [73].

The X-ray diffractograms obtained on the different samples showed clear resemblances and differences. The representative X-ray diffractograms shown in Figures 5(a)-(c) revealed the presence quartz and kaolin in all the clays. All clays studied had abundant quartz because they were transported by erosion to valleys where they were mined. Quartz represents unaltered clay precursors. The distribution of the various clay minerals and clay precursors are shown as interpreted on Figures 5(a)-(c). The Central Uganda clays are represented by the sample from Kajansi (Figure 5(c)) which has been shown to contain kaolinite (K), halloysite (H) and quartz (Q) as main minerals. This has been interpreted to show that these clays formed from quartz diorites and presence of quartz is a sign of presence of parent rocks.

The volcanic clays from Sironko and Kapchorwa are represented by the Mutufu and Chelel clays respectively (Figure 5(a) and Figure 5(b)) and have been shown to contain smectite (S), illite (I), kaolinite (K), K-fedspars (Kf), plagioclase (Pc) and quartz (Q) [13]. The presence of feldspars and plagioclase in these clays showed that the parent rocks were volcanic ashes and that these clays were younger than Central Uganda clays.

As the XRD patterns in Figure 5(c) show high abundancy of kaolinite and halloysite, the sampled clays were kaolinites [71]. The XRD patterns in Figure 5(a) and Figure 5(b) for selected clays from Mutufu and Chelel showed presence of nontronite and kaolinite as mixtures containing feldspars and plagioclase. The structures of these clays resemble Figure 4 [8].

The clays from Central Uganda had kaolin as the dominant clay mineral yet clays from volcanic sediments in Eastern Uganda nontronite as clay mineral.

\subsection{Differential Thermal Analyses (DTA)}

DTA curves showed that clays from Central Uganda contained kaolinites as they showed peaks at $150^{\circ} \mathrm{C}, 530^{\circ} \mathrm{C}$ and $600^{\circ} \mathrm{C}$. As kaolinites show minimal bleaching tendancy and surface acidity, it can be concluded that DTA curves can be used to identify kaolinites and smectites. The basis that smectites gain bleaching capacity at faster rate than kaolinites, it can be inferred that DTA curves can be used to identify clays that can be very useful as bleaching earths. Generally, DTA curves showed a small change in the endothermic peak after acid treatment, corresponding to the loss of adsorbed water (at about $150^{\circ} \mathrm{C}$ ), and peaks corresponding to the loss of structural hydroxyl groups $\left(530^{\circ} \mathrm{C}\right.$ and $\left.600^{\circ} \mathrm{C}\right)$ [72]-[74].

The endothermic peak in the range of temperatures between $550^{\circ} \mathrm{C}$ and $660^{\circ} \mathrm{C}$ is attributed to dehydration of the mineral leading to formation of $\gamma$-aluminium oxide in kaolinite clays [75]. The halloysites showed the same thermal reactions as kaolinites with additional sharp endothermic peak in the temperature range of $100^{\circ} \mathrm{C}$ and $150^{\circ} \mathrm{C}$ accompanying loss of water and transition to metahalloysite [76].

DTA curves show no evidence of the difference between halloysite and kaolinite except for the difference in the initial endothermic peaks representing water loss at low energy levels [72]. The differential thermal analysis data presented in Figure 6 showed that the clays lost inter layer water molecules in the temperature range between $210^{\circ} \mathrm{C}$ and $230^{\circ} \mathrm{C}$. The clay samples studied exhibited endothermic peaks at $140^{\circ} \mathrm{C}$ and $210^{\circ} \mathrm{C}$ due to loss of hydration water [33] [77].

Both kaolinite-rich and smectite clays showed exothermic peaks in the range of $900^{\circ} \mathrm{C}-1000^{\circ} \mathrm{C}$. Figure 6 shows 


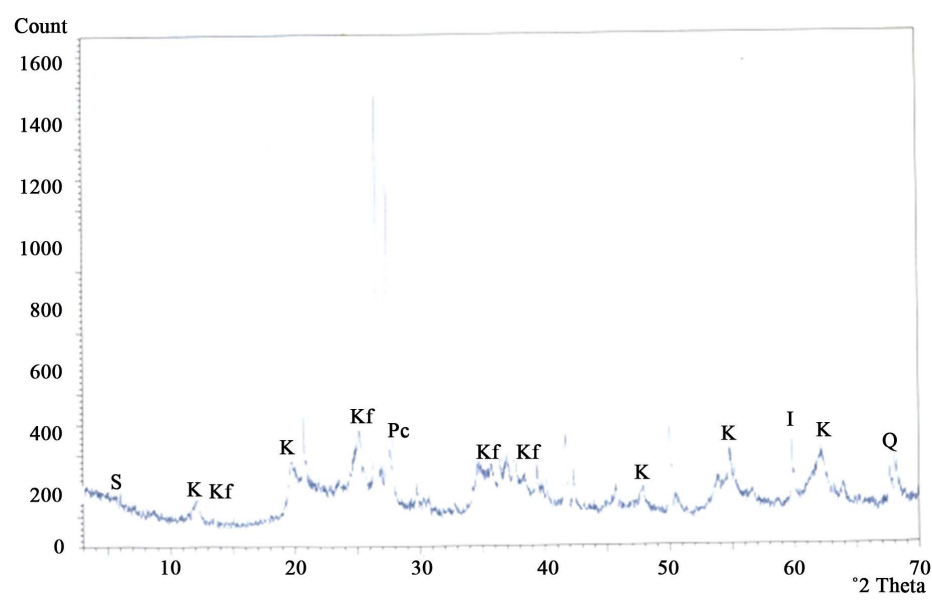

(a)

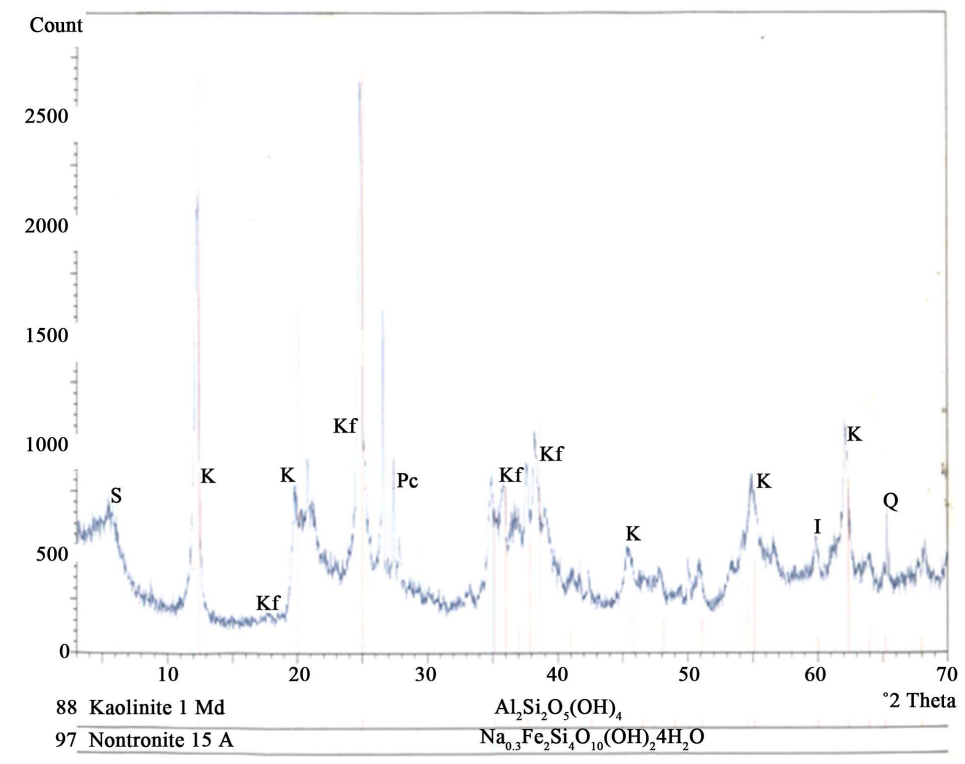

(b)

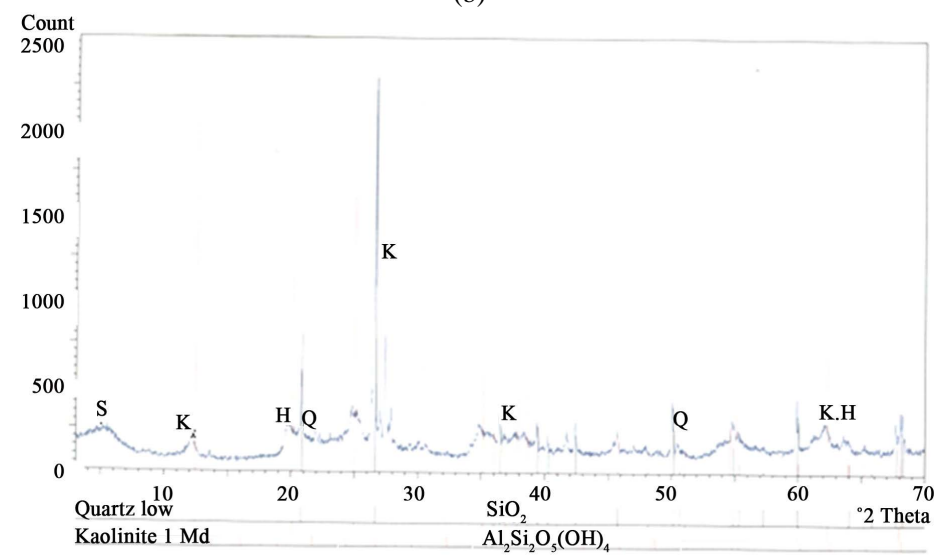

(c)

Figure 5. a) XRD pattern of clay sediments selected from Mutufu, Key: smectite (S), illite (I), kaolinite (K), K-fedspars (Kf), plagioclase (Pc) and quartz (Q); b) XRD pattern of selected clay from Chelel, Key: smectite (S), illite (I), kaolinite (K), K-fedspars (Kf), plagioclase (Pc) and quartz (Q); c) XRD pattern of Kajansi clay. Key: smectite (S), kaolinite (K), halloysite (H) and quartz (Q). 


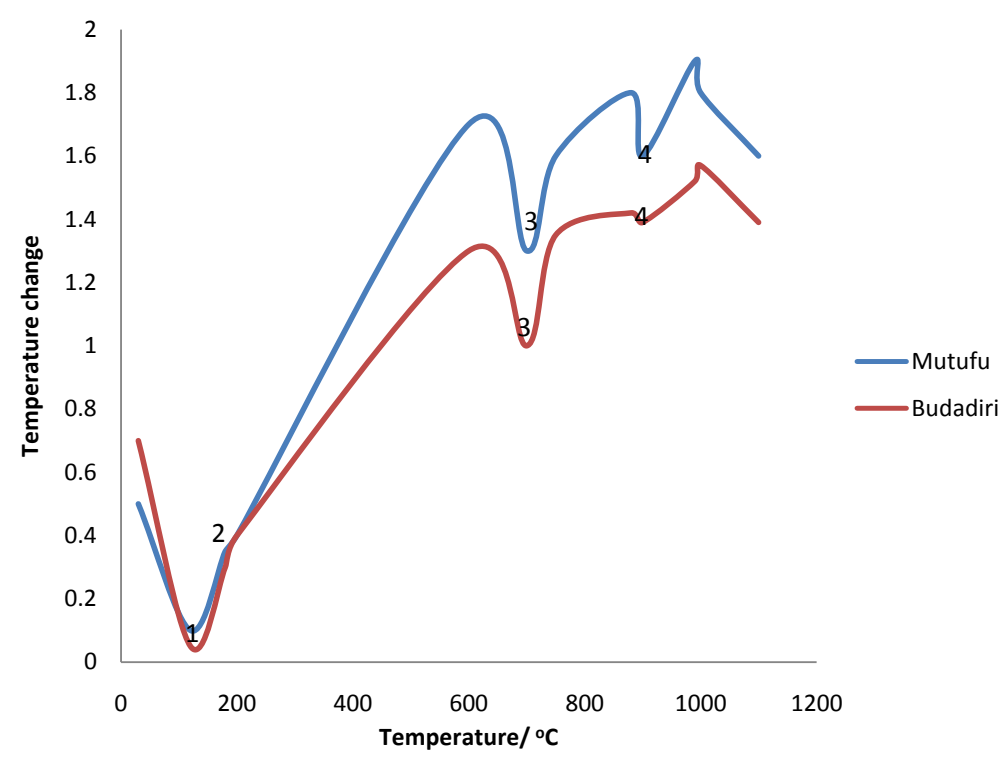

Figure 6. Representative thermal differential analyses. Key: For all the curves above: 1 is dehydration, 2 is dehydroxylation, 3 is calcinations and 4 is recrystallisation.

that the selected clays from Uganda give endothermic and exothermic peaks in differential thermal analyses [78] [79].

Illites showed the endothermic peaks in the temperatures between $100^{\circ} \mathrm{C}$ and $200^{\circ} \mathrm{C}, 500^{\circ} \mathrm{C}$ and $650^{\circ} \mathrm{C}$ and at about $900^{\circ} \mathrm{C}$. This gives three endothermic peaks. The second peak in the temperature range of $500^{\circ} \mathrm{C}$ to $650^{\circ} \mathrm{C}$ represents loss of most of the water from the clay lattice. The third peak is associated with destruction of crystal structure [79]. Halloysite, kaolinite and illite show endothermic peak at temperature between $500^{\circ} \mathrm{C}$ and $600^{\circ} \mathrm{C}$ attributed to loss of water [72]. Montmorillonite showed initial endothermic peak at temperature between $100^{\circ} \mathrm{C}$ and $250^{\circ} \mathrm{C}$ due to loss of water held between the basal planes of the lattice structure [76]. The initial peak is large and extended over a wide temperature range, indicating that the clay possessed water molecules other than pore water which causes no thermal reaction above $100^{\circ} \mathrm{C}$. Lattice water is lost at temperatures higher than $100^{\circ} \mathrm{C}$ [79] [80].

The thermal stability of montmorillonites is related to crystalline structure (Lombardi et al., 2002). The loss of hydroxide ions from clay material causes irreversible modification of the crystal structure, producing the endothermic peak at temperatures between 650 and $700^{\circ} \mathrm{C}$ [78] which suggests high thermal stability in these clays.

The deformations in crystal structure of montmorillonite clay are initiated by different isomorphic substitutions which cause a temperature shift of the peak [81]. The higher the degree of octahedral substitution is, the lower the hydroxyl release temperature is [74]. The high octahedral substitution of iron in montorillonite clay causes a shift of the endothermic peak from near $600^{\circ} \mathrm{C}$ to $544^{\circ} \mathrm{C}$ due to isomorphic substitutions of the 0.60 octahedral of the bentonite [74].

The DTA curves for the selected clay from Mutufu and Budadiri (Figure 6) correlated with those published [74]. This showed that the selected clays have similar structure to montmorillonite. Similarly, DTA curves for selected clays from Kajansi, and Kawuku were similar to those published by different authors [78] [79]. So these clays contained kaolinites and halloysites [82].

\section{Conclusions}

The results on the elemental and mineralogical compositions of clays from Central Uganda differ from those from the volcanic sediments of the Mt. Elgon. Utilisation of the two types of clays should be strict. Whereas elemental and mineralogical data on selected clays from Kumi, Nakawa, Seeta, Kajansi, Kawuku, Lwanda, Chodah and Umatengah indicated they were kaolinites. The XRD, IR and DTA data on clays from Mutufu, Budadiri, Chelel and Siron indicated they are smectites. So clays to be used to develop bleaching earths should be selected from smectites. 
The pH data on Nakawa, Kawuku, Kajansi, Umatengah, Chodah, Seeta, Lwanda and Kumi clays indicated they are acidic kaolinites. The Mutufu, Budadiri, Siron and Chelel clays have been shown to be smectites.

The IR data accumulated on Kawuku, Kajansi, Lwada, Seeta, Chodah, Umatengah, Kumi and Nakawa clays revealed they were largely kaolinites yet that on Mutufu, Chelel, Budadiri and Siron clays indicated they were smectite-rich.

\section{Acknowledgements}

We thank Mr. Edward Ssekubunga for heating the clay samples studied in the furnace, Mr. Moses Nkolongo (rest in peace) for availing us chance to use the spectrophotometers in the analytical laboratories and Professor Ludwig of Institut für Mineralogie, Federal Republic of Germany for running XRD patterns of clays used in the study.

\section{References}

[1] Bailey, S.W. and Brindley, G.W. (1979) Structure of Basic Clay Mineralogy Groups. Clay Mineral, 27, $238-239$.

[2] Parker, S.P. (1996) McGraw-Hill Dictionary of Earth Sciences. McGraw-Hill, New York.

[3] Nguetnkam, J.P., Kamga, R., Villieras, F., Ekodeck, G.E. and Yvon, J. (2008) Assessing the Bleaching Capacity of Some Cameroonian Clays on Vegetable Oils. Applied Clay Science, 39, 113-121.

[4] Houdry, E., Burt, W.F., Pew, A.B. and Peters, W.A. (1938) Catalytic Processing by the Houdry Process. Nat. Petroleum News, 39, R570-R580.

[5] Bailey, S. (1980) Summary of the Recommendations of AIPEA Nomenclature Committee on Clay Minerals. American Mineralogist, 65, 1-7.

[6] Kerr, P.F. (1952) Formation and Occurrence of Clay Minerals. Clays and Clay Minerals, 1, 19-32. http://dx.doi.org/10.1346/CCMN.1952.0010104

[7] Jepson, W.B. and Browse, J.B. (1975) The Composition of Kaolinite-An Electron Microbe Study. Clays and Clay Minerals, 23, 310-317. http://dx.doi.org/10.1346/CCMN.1975.0230407

[8] Bain, C.D. and Nadeau, P.H. (1986) Composition of Some Smectites and Diagenetic Illitic Clays and Implications for Their Origin. Clays and Clay Minerals, 34, 455-464. http://dx.doi.org/10.1346/CCMN.1986.0340412

[9] Gates, K. (2002) Site Occupancies by Iron in Nontronites. Clays and Clay Minerals, 50, 223-239. http://dx.doi.org/10.1346/000986002760832829

[10] Deer, W.A., Howie, R.A. and Zussman, J. (1992) An Introduction to the Rock-Forming Minerals. 2nd Edition, Longman, London, 496-502.

[11] Guggenheim, S. and Martin, R.T. (1993) Definition of Clay and Clay Mineral: Joint Report of the AIPEA Nomenclature and CMS Nomenclature Committees. Clays and Clay Minerals, 43, 255-256.

[12] Longstaffe, F.J. (1981) Short Courses in Clays and Resources (Geology). 7, 245-450.

[13] Christidis, G. and Marcopolous, T. (1992) Kaolinite Generating Processes in the Milos Bentonites and Their Influence on the Physical Properties of Bentonites. The 6th International Congress of the Geological Society of Greece, Athens, 25-27 May 1992, 28-29.

[14] Cameron, K.L. and Blatt, H. (1971) Durabilities of Sand Size Schist and “Volcanic” Rock Fragments during Fluvial Transport, Elk Creek, Black Hills, South Dakota. Journal of Sedimentary Research, 41, 565-576. http://dx.doi.org/10.1306/74D722D4-2B21-11D7-8648000102C1865D

[15] Hower, J., Everett, P. and Powl, T. (1976) Phase Relations among Smectite, Illite-Smectite, and Illite. Clays and Clay Minerals, 38, 449-468.

[16] Velde, B., Suzuki, T. and Nicot, E. (1986) Pressure-Temperature-Composition of Illite/Smectite Mixed-Layer Minerals: Niger Delta Mudstones and Other Examples. Clays and Clay Minerals, 34, 435-441. http://dx.doi.org/10.1346/CCMN.1986.0340410

[17] Howard, J.J. and Roy, D.M. (1985) Development of Layer Charge and Kinetics of Experimental Smectite Alteration. Clays and Clay Minerals, 33, 81-88. http://dx.doi.org/10.1346/CCMN.1985.0330201

[18] Robertson, H.E. and Lahann, R.W. (1981) Smectite to Illite Conversion Rates: Effects of Solution Chemistry. Clays and Clay Minerals, 29, 129-135. http://dx.doi.org/10.1346/CCMN.1981.0290207

[19] Eberl, D. (1978) The Hydrothermal Transformation of Sodium and Potassium Smectite into Mixed-Layer Clay. Clays and Clay Minerals, 25, 215-227. http://dx.doi.org/10.1346/CCMN.1977.0250308

[20] Whitney, G. and Northrop, H.R. (1988) Smectite to Illite Reaction. Mechanism of Illitization of Bentonites in the Geothermal Fields. American Mineralogist, 73, 77-90. 
[21] Baronnet, A. (1982) Ostwald Ripening in Solution the Case Ofcalcite and Mica. Estudios Geologicos (Madrid), 38, 185-198.

[22] Eberl, D.D., Srodon, J., Kralik, M., Taylor, B.E. and Peterman, Z.E. (1990) Ostwald Ripening of Clays and Metamorphic Minerals. Science, 248, 474-477. http://dx.doi.org/10.1126/science.248.4954.474

[23] Drits, V.A., Salyn, A.L. and Sucha, V. (1996) Structural Transformation of Interstratified Illite-Smectites from Dolná ves Hydrothermal Deposits: Dynamics and Mechanism. Clays and Clay Minerals, 44, 181-190. http://dx.doi.org/10.1346/CCMN.1996.0440203

[24] Mathers, S.J. and Mitchell, C.J. (1992) Industrial Mineral of Uganda: An Interim Report. British Geological Survey Technical Report WC 19217 R, Nottingham, 35-36.

[25] Mathers, S.J. (1998) Exploration and Evaluation of Industrial Mineral Potential of Uganda. British Geological Survey Technical Report WG/98/33R, Nottingham, 23-25.

[26] Keller, W.D. (1957) Principles of Chemical Weathering. Lucas Bros., Columbia, 111.

[27] Grifffin, G.M. (1962) Regional Clay Mineral Facies Development in Recent Surface Sediments of the Northern Gulf of Mexico. Lucas Bros., Pub., Columbia, 123-124.

[28] Altaner, S.P. and Grim, R.E. (1990) Mineralogy, Chemistry and Diagenesis of Tuffs in the Sucker Creek Formation of Eastern Oregon. Clays and Clay Minerals, 38, 561-572. http://dx.doi.org/10.1346/CCMN.1990.0380601

[29] Elzea, J.M. and Murray, H.H. (1990) Variation in Mineralogical, Chemical and Physical Properties of Cretaceous Clay Spur Bentonite in Wyoming and Montana. Applied Clay Science, 5, 229-248. http://dx.doi.org/10.1016/0169-1317(90)90012-E

[30] Jeans, C.V., Merriman, R.J. and Mitchell, J.G. (1983) Significance of Changes in Clay Mineralogy of Jurassic Sediments in France and England. Clay Mineralogy, 12, 11-14.

[31] Charnley, H. (1989) Clay Sedimentology. Springer-Verlag, Berlin.

[32] Mukasa-Tebandeke, I.Z., Ssebuwufu, P.J.M., Lugolobi, F., Nyanzi, S., Schumann, A. and Kirsch, N. (2003) The Bleaching Clays of Central and Eastern Uganda: The Relation between Mineralogy and Chemical Composition to Bleaching Properties. International Journal of Environmental Issues, 1, 20-29.

[33] Nyakairu, G.W.A. and Koeberl, C. (2001) Mineralogical and Chemical Composition and Distribution of Rare Earth Elements in Clay-Rich Sediments from Central Uganda. Geochemical Journal, 35, 13-28. http://dx.doi.org/10.2343/geochemj.35.13

[34] Sharma, D. (1972) Kaolin Deposits at Namasera Hill. Department of Geological Surveys and Mines, Report AJR/25, Entebbe, 25.

[35] Reedman, A.J. (1969) Interim Report on Beryl Pegmatites in Southwest Uganda. Department of Geological Surveys and Mines, Unpublished Report AJR/25, Entebbe, 25.

[36] Farmer, V.C. (1974) The Layer Silicates. In: Farmer, V.C., Ed., The Infrared Spectra of Minerals, Mineralogical Society, London, 331-363.

[37] Knechtel, M.M. and Patterson, S.H. (1962) Clay Spur of Hyomngiolive-Green. United States Geology Survey Bulletin, 1023, 115-116.

[38] Komadel, P., Lear, R.P. and Stucki, J.W. (1990) Reduction and Reoxidation of Nontronite: Extent of Reduction and Reaction Rates. Clays and Clay Minerals, 38, 203-208. http://dx.doi.org/10.1346/CCMN.1990.0380212

[39] Wilson, M.J., Russell, J.D. and Tait, J.M. (1974) A New Interpretation of the Structure of Disordered $\alpha$-Cristobalite. Contributions to Mineralogy and Petrology, 47, 1-6. http://dx.doi.org/10.1007/BF00418553

[40] Hutchison, C.S. (1974) Laboratory Handbook of Petrographic Techniques. John Wiley \& Sons, Inc., New York, 234240.

[41] Reynolds Jr., R.C. and Moore, D.M. (1989) Principles and Techniques of Quantitative Analysis of Clay Minerals by X-Ray Powder Diffraction. Oxford University Press, New York, 332-337.

[42] Russell, J.D. (1979) Instrumentation and Techniques. Infrared Spectra of Minerals. London Mineral Society, London.

[43] Evans, L.T. and Russell, E.W. (1959) The Adsorption of Humic and Fulvic Acids by Clays. Journal of Soil Science, 10, 119-132. http://dx.doi.org/10.1111/j.1365-2389.1959.tb00672.x

[44] Beneke, K. and Lagaly, G. (2002) ECGA (European Clay Group Association). Newsletter, No. 5, 57-78.

[45] Fahn, R. (1976) Bleaching Earths-Preparation, Properties, Practical Applications. Chapter 1, International Symposium, Brussels, 28-29.

[46] Srodon, J. (1984) X-Ray Powder Diffraction Identification of Illitic Minerals. Clays and Clay Minerals, 32, $337-349$. http://dx.doi.org/10.1346/CCMN.1984.0320501

[47] Christidis, G.E. (1998) Physical and Chemical Properties of Some Bentonite Deposits of Kimolos Islands, Greece. Ap- 
plied Clay Science, 13, 79-98. http://dx.doi.org/10.1016/S0169-1317(98)00023-4

[48] Hartwell, J.M. (1965) The Diverse Uses of Montmorillonite. Clay Minerals, 6, 111-118. http://dx.doi.org/10.1180/claymin.1965.006.2.05

[49] O’D Alexander, C.M., Barber, D.J. and Hutchison, R. (1989) The Microstructure of Semarkona and Bishunpur. Geochimica et Cosmochimica Acta, 53, 3045-3057.

[50] Scott, A., Dinesh, T., Kohlenberger, L.H. and Blair, F.G. (1969) Ceramic Abstracts. Journal of the American Ceramic Society, 52, 303-334. http://dx.doi.org/10.1111/j.1151-2916.1969.tb09193.x

[51] Brady, N. and Weil, R. (2002) The Nature and Properties of Soils. 13th Edition, Pearson Education, Inc., Upper Saddle River.

[52] Al-Bakri, D., Khalaf, F. and Al-Ghadban, A. (1984) Mineralogy, Genesis, and Sources of Surficial Sediments in the Kuwait Marine Environment, Northern Arabian Gulf. Journal of Sedimentary Research, 54, 1266-1279.

[53] Hamza, A. (1966) An Investigation on the Utilization of Egyptian Clays in Bleaching of Cotton Seed Oil. M.Sc. Thesis, Alexandria University, Alexandria.

[54] Grim, W.F. (1951) Clay Mineralogy and Petroleum Industry. American Mineralogist, 36, 182-201.

[55] Moore, D. (1997) X-Ray Diffraction and the Identification and Analysis of Clay Minerals. Oxford University Press, New York.

[56] Brown, G. and Brindley, G.W. (1980) X-Ray Diffraction Procedures for Clay Mineral Identification. In: Brindley, G.W. and Brown, G., Eds., Crystal Structures of Clay Minerals and Their X-Ray Identification, Mineralogical Society, London, 339-346.

[57] Christidis, G. and Dunham, A.C. (1993) Compositional Variations in Smectites: Part I. Alteration of Intermediate Volcanic Rocks. A Case Study from Milos Island, Greece. Clay Minerals, 28, 255-273. http://dx.doi.org/10.1180/claymin.1993.028.2.07

[58] Nyakairu, G.W.A. and Kahwa, J. (1998) Phase Transitions in Local Clays. American Ceramic Society Bulletin, 77, 76-78.

[59] Mills, G.A., Holmes, J. and Cornellius, E.B. (1950) The Acid Activation of Some Bentonite Clays. Journal of Physical Chemistry, 54, 1170-1185. http://dx.doi.org/10.1021/j150482a009

[60] Nutting, P. (1935) The Bleaching Earths. Bull. Am. Petroleum Geol., 19, 1045.

[61] Didi, M.A., Makhoukhi, B., Azzouz, A. and Villemin, D. (2009) Colza Oil Bleaching through Optimized Acid Activation of Bentonite. A Comparative Study. Applied Clay Science, 42, 336-344. http://dx.doi.org/10.1016/j.clay.2008.03.014

[62] Schlumberger, J. (1987) Log Interpretation Principles/Applications. Schlumberger Education Services, Houton, 69-94.

[63] Christidis, G.E., Scott, P.W. and Marcopoulos, T. (1995) Origin of the Bentonite Deposits of Eastern Milos, Aegean, Greece: Geological, Mineralogical and Geochemical Evidence. Clays and Clay Minerals, 43, 63-77. http://dx.doi.org/10.1346/CCMN.1995.0430108

[64] Christidis, G.E. and Scott, P.W. (1997) The Origin and Control of Colour of White Bentonites from the Aegean Islands of Milos and Kimolos, Greece. Mineralium Deposita, 32, 271-279. http://dx.doi.org/10.1007/s001260050092

[65] Christidis, G.E. (1993) Comparative Study of Mobility of Major and Trace Elements in Bentonites of Milos Island. Bulletin of Geological Society of Greece, 165-173.

[66] Grim, R.E. (1942) Modern Concepts of Clay Minearlas. Presented at 50th Anniversary, University of Chicago Founding, Chicago, Journal of Geology, 50, 225-275. http://dx.doi.org/10.1086/625050

[67] Nagudi, B., Koeberl, C. and Kurat, G. (2000) Petrography and Geochemistry of the Singo Granite, Uganda and Implications of Its Origin. Journal of African Earth Sciences, 30, 65-66.

[68] McKinley, J.M., Worden, R.H. and Ruffell, A.H. (2003) Smectite in Sandstones: A Review of Controls on Occurrence and Behavior during Diagenesis. International Association of Sedimentologists, 109-118.

[69] Nyakairu, G.W.A., Kurzweil, H. and Koeberl, C. (2002) Mineralogical, Geochemical and Sedimentological Characteristics of Clay Deposits from Central Uganda and Their Applications. Journal of African Earth Sciences, 35, 123-134. http://dx.doi.org/10.1016/S0899-5362(01)00077-X

[70] Ball, D.F. (1964) Loss on Ignition as an Estimate of Organic Matter and Organic Carbon in Non-Calcareous Soils. The Nature Conservancy, Bangor, 85.

[71] Volzone, C., Zalba, P.E. and Pereira, E. (1988) Activación ácida de esmectitas. II—Estudo mineralogico. Anales de la Asociación Química Argentina, 76, 57-68.

[72] Brindley, G.W. (1981) Structures and Chemical Composition of Clay Minerals. In: Longstaffe, F.J., Ed., Clays and Resource Geologist, Mineralogical Association of Canada, Alberta, 1-12. 
[73] Grim, R.E. (1958) Concept of Diagenesis in Argillaceous Sediments. AAPG Bulletin, 42, 246L-253L.

[74] Brindley, G.W. and Brown, G. (1980) X-Ray Diffraction Procedures for Clay Mineral Identification. In: Brindley, G.W. and Brown, G., Eds., Crystal Structures of Clay Minerals and Their X-Ray Identification, Mineralogical Society, 305-356.

[75] Lomdardi, K.G., Guimaraes, J.L., Mangrich, S.A., Mattoso, N., Abbate, M., Schreier, H.W. and Wypych, F. (2002) Structural and Mineralogical Characterisation of pp-0559 Kaolinite from Brazilian Amazon Region. Journal of the Brazilian Chemical Society, 13.

[76] Insley, H. and Ewell, R.H. (1938) Thermal Behavior of Kaolin Minerals. Journal of Research of the National Bureau of Standards, 14, 615-627. http://dx.doi.org/10.6028/jres.014.037

[77] Hendricks, S.B. (1938) On the Structure of Clay Minerals, Dickite, Halloysite, Hydrated Halloysite. American Mineralogist, 23, 275-301.

[78] Grim, R.E. and Bradley, W.F. (1940) Investigation of the Effect of Heat on Clay Minerals Illite and Montmorillonite. Journal of the American Ceramic Society, 23, 242-248. http://dx.doi.org/10.1111/j.1151-2916.1940.tb14263.x

[79] Sudo, T. and Shimada, S. (1970) In: Mackenzie, R., Ed., Differential Thermal Analysis, Academic Press, Waltham, 539-540.

[80] Hendricks, S.B. and Jefferson, M.E. (1940) Structures of Kaolin and Talc-Pyrophyllite Hydrates and Their Bearing on Water Sorption of Clays. American Mineralogist, 23, 863-875.

[81] Siguin, D., Ferreira, S., Foure, L. and Garcia, F. (1995) Relationship between Isomorphic Substitutions and the Thermal Degradation of Bentonites. Journal of the American Ceramic Society, 78, 2215-2219. http://dx.doi.org/10.1111/j.1151-2916.1995.tb08640.x

[82] Brindley, G.W. (1978) Preparation and Properties of Some Hydroxyl Aluminium Beidellites. Ceramica, 24, $217-224$. 
Scientific Research Publishing (SCIRP) is one of the largest Open Access journal publishers. It is currently publishing more than 200 open access, online, peer-reviewed journals covering a wide range of academic disciplines. SCIRP serves the worldwide academic communities and contributes to the progress and application of science with its publication.

Other selected journals from SCIRP are listed as below. Submit your manuscript to us via either submit@scirp.org or Online Submission Portal.
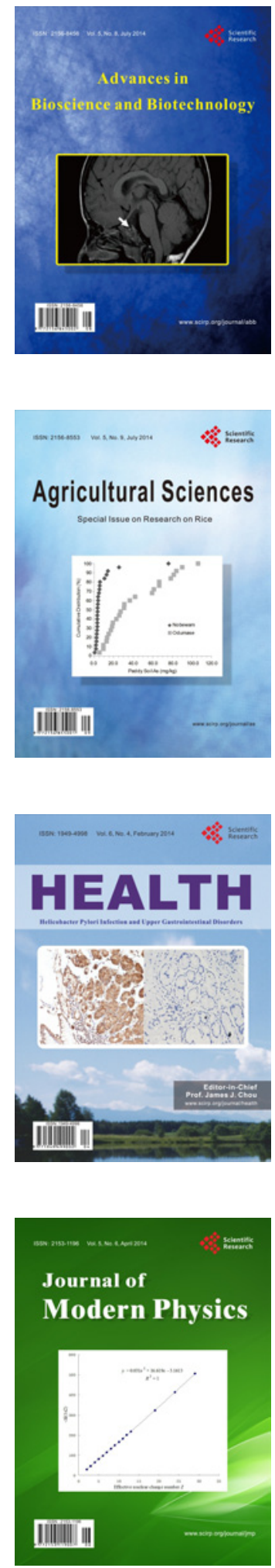
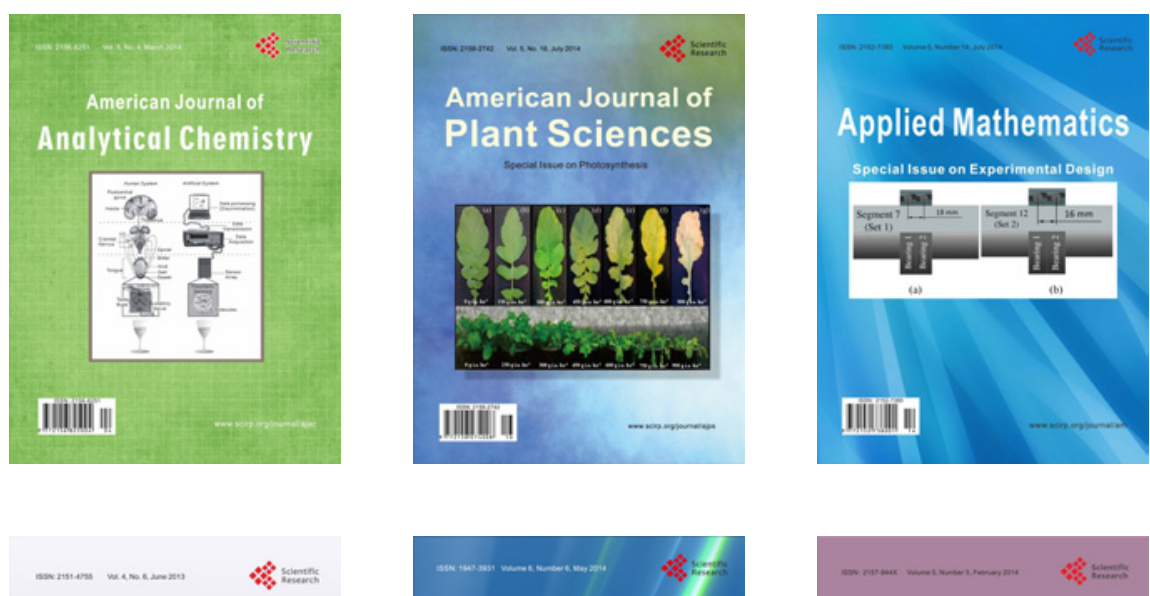

Creative Education
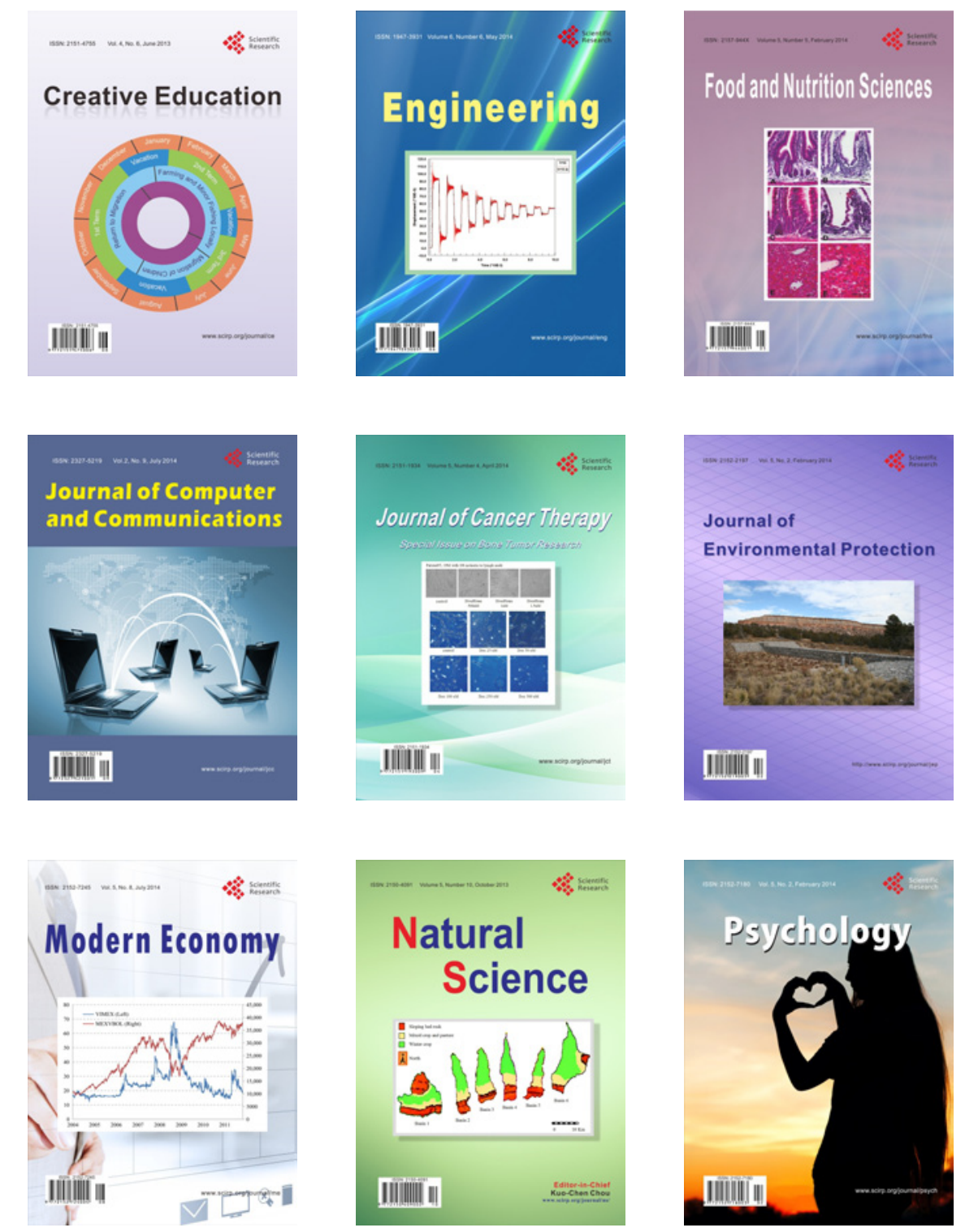